\title{
Measurement of rill erosion through a new UAV-GIS methodology
}

\author{
Paolo Bazzoffi
}

CREA-ABP Council for Agricultural Research and Economics, Agrobiology and Pedology Research Centre, Firenze, Italy

Corresponding author: Paolo Bazzoffi

E-mail: paolo.bazzoffi@crea.gov.it

Key words: Rill erosion; soil erosion measurement; UAV; drone; GIS; CAP.

Work done under the Project MO.NA.CO. (National network for monitoring the environmental effectiveness of cross compliance and the differential of competitiveness charged against agricultural enterprises) funded by the Ministry of Agricultural, Food and Forestry Policies (MiPAAF) in the context of Action 1.2.2 "Interregional Workshops for development" of the Operational Programme called "National Rural Network 2007-2013", Coord. Paolo Bazzoffi.

Acknowledgments: the author greatly thanks the Geographike Srl firm in Siena that performed the UAV survey. In particular Dr. Michele Bocci and Dr. Valerio Volpi are greatly aknowledged for their help and guidance. Dr. Rosa Francaviglia, Dr. Rosario Napoli, Ulderico Neri, of the CREA-RPS (Rome) Research centre are also acknowledged for their assistance during the field survey at Tor Mancina. Dr. Giovanni L'Abate research fellow at the CREA-ABP Research Centre of Florence is acknowledged for his help in some preliminary Microsoft Access analyses. The author likes to thank Flavia Bazzoffi for the peer revision of English.
CCopyright P. Bazzoffi, 2015

Licensee PAGEPress, Italy

Italian Journal of Agronomy 2015; 10(s1):708

doi:10.4081/ija.2015.708

This article is distributed under the terms of the Creative Commons Attribution Noncommercial License (by-nc 3.0) which permits any noncommercial use, distribution, and reproduction in any medium, provided the original author(s) and source are credited.

\section{Abstract}

Photogrammetry from aerial pictures acquired through micro Unmanned Aerial Vehicles (UAV), integrated by post-processing is a promising methodology both in terms of speed of data acquisition, degree of automation of data processing and cost-effectiveness. The new UAV-GIS methodology has been developed for three main purposes: i) for a quick measurement of rill erosion at a field scale with the aim of combining the simplicity of field survey to reliability of results, at an affordable price; ii) to calibrate the RUSLE model to make it suitable for the purposes of the CAP common indicator; iii) to provide an easy evaluation tool to Regions and to non-research professionals who use the very popular ESRI ArcGis software for assessing the effectiveness of soil conservation measures adopted under CAP and to calibrate the common indicator 'soil erosion by water'. High-resolution stereo photos pairs, acquired close to the soil, are of crucial importance in order to produce high resolution DEMs to be analysed under GIS. The GIS methodology consists of the measurement of rill erosion that occurred in a plot from the total volume of the incisions, regardless of internal sediment redeposition, based on Plan Curvature analysis and Focal Statistics analysis, described in detail, as they are the essential constituents of the new methodology. To determine the effectiveness and reliability of the new methodology a comparison between rill depth measured manually on field of 51 rill points and depth measured by UAV-GIS methodology was done. The best calibration equation was obtained by using $30 \mathrm{~cm}$ radius in the Focal statistics analysis. The linear regression equation resulted highly significant with $R^{2}=0.87$. Two case studies are presented, solved step by step, in order to help the user to overcome possible difficulties of interpretation in the application of the GIS procedure. The first solved exercise concerns a heavily eroded plot where only one DEM, derived from post erosion UAV photos, was used to calculate rills erosion. In this case, incisions due to tillage tools and wheel tracks (false rills) which were present on the soil surface before soil erosion had occurred were no longer present at flight time, as they have been fully incorporated (absorbed) by rills. The second exercise concerns a less rilled plot, where the diachronic analysis of DEMs was deemed necessary to subtract from the rill volume the false rill volume which was still present on the soil surface before soil erosion has occurred. In this case rill erosion increased the volume of preexisting mechanical incisions that are still distinguishable (with the naked eye on the field) from the incision forms due to runoff water. A solved exercise to assess interrill erosion from the calculated value of rill erosion, according to a previous study of 1989, is also reported. A comparison between UAV-GIS measured and RUSLE predicted erosion rates is also reported, which gives a first confirmation of validity of the new methodology. 


\section{Preface}

Soil erosion by water is one of the most widespread forms of soil degradation in Europe, largely due to intensification of agriculture on sloped land. Eurostat (2013) reports that approximately 15\% of the European Union territory (with the exclusion of Cyprus, Greece and Malta) is estimated to be affected by medium to high level of soil erosion rate (spanning 3-30 tha-1 year-1) and $1 \%$ of the EU land surface suffers from extreme erosion (over $30 \mathrm{t} \mathrm{ha}^{-1}$ year-1). Since the mid1980 s, agri-environmental policies have started been implemented in all European Union (EU) countries as a response to EU regulations. In the 1990s the Mac Sharry's reform consistently integrated environmental concerns into the Common Agricultural Policy (CAP), followed in this process by the Fischler's reform (EU REG.1782/2003), by the 'Thematic strategy for soil protection' (EC, 2012) and by the Europe 2020 Strategy (EC, 2010).

In the CAP, environmental issues can be reached on the basis of the distinction between two main goals:

i) Ensuring a sustainable way of farming by avoiding environmentally harmful agricultural activity. In this context farmers, according to the 'Polluter-Pays-Principle', are obliged to respect mandatory 'Cross-compliance' rules and $\mathrm{GAEC}^{2}$ standards (forming the 'reference level' or 'baseline') and 'greening' obligations, for preserving the environment and the landscape. These commitments are implemented under the first pillar of CAP supported by EAGF (European Agricultural Guarantee Fund).

ii) Providing incentives for environmentally beneficial public goods and services which are of interest to the wider public and society beyond the mandatory requirements, according to the "provider-getsprinciple' (where farmers are remunerated for voluntarily engaging in environment-related activities). Incentives to farmers are given so as to adopt specific agri- environment measures implemented by Rural Development Programmes (RDP) under the second pillar of CAP, supported by EAFRD (European Agricultural Fund for Rural Development).

In order to be accountable, policy outcomes need to be assessed against stated objectives. Also the process of integrating environmental concerns into the Common Agricultural Policy needs regular assessments. In the EU, an elaborated approach towards regular policy evaluation has been established at European, national, or regional level.Specific agri-environmental indicators are a helpful tool for policy assessment, as they capture trends effectively as well as developments over time.

The Regulation (EU) No. 808/2014, which codifies the application of Regulation (EU) No. 1305/2013, entails that for each focus area included in the RDP, the related question must be answered in the enhanced annual implementation reports (AIRs) that will be due in 2017 and 2019, and in the ex-post evaluation report. For the Focus area $4 \mathrm{C}$ (Preventing soil erosion and improving soil management), the evaluation question is: 'To what extent have RDP interventions supported the prevention of soil erosion and improvement of soil management?' To answer such a question, the appropriate indicator to quantify soil erosion can be found in the list of EU common indicators given by the European Evaluation Network for Rural development (ENRD, 2013). The common indicator 'soil erosion by water' is defined as the mean rate of soil loss by water erosion $\left(\mathrm{t} \mathrm{ha} \mathrm{h}^{-1}\right.$ year-1) as estimated on a regional scale by the RUSLE model (Renard et al., 1997).

\section{Aim of the UAV-GIS methodology}

The new UAV-GIS methodology has been developed for three main purposes: i) for a quick measurement of rill erosion at a field scale with the aim of combining the simplicity of field survey to precision of results, at an affordable price; ii) to calibrate the RUSLE model to make it suitable for the purposes of the CAP common indicator for the Italian environment; and iii) to provide a ease tool to technical regional services, independent evaluators ${ }^{3}$ responsible for the evaluation or rural development plans and non-research professionals who use the very popular ESRI ArcGis software. In this regard, the methodology has been designed to solve specific problems of monitoring the effectiveness of agronomic actions implemented in Italy within the framework of the CAP to combat soil erosion. This provides a fast method that allows the comparison of soil erosion rates between factual and counterfactual (namely, 'in application' versus 'non-application' of agronomic actions dictated by GAEC Cross-compliance Standards and by Agri-environmental measures of national and/or regional rural development programmes (RDPs). As already stated, the common indicator 'soil erosion by water' must be estimated under CAP on a regional scale by the RUSLE model. Anyway, some problem can arise when this model is applied without any calibration.

RUSLE is a predictive model developed by the USDA-Agricultural Research Service for use as a conservation planning designed to predict long-term annual averages of soil loss. This model derives from the previous model USLE (Wischmeier and Smith, 1978) and is a parametric equation as follows:

$$
\text { A = R.K.LS.C.P }
$$

where

$\mathrm{A}=$ Soil loss in $\mathrm{t} \mathrm{ha}^{-1}$ over a period selected for $\mathrm{R}$, usually on a yearly basis;

$\mathrm{R}=$ Rainfall-runoff erosivity factor in $\mathrm{MJ} \mathrm{mm} \mathrm{ha}{ }^{-1} \mathrm{hr}^{-1} \mathrm{yr}^{-1}$;

$\mathrm{K}=$ Soil erodibility factor in $\mathrm{th} \mathrm{MJ}^{-1} \mathrm{~mm}$;

$\mathrm{L}=$ Slope length factor (dimensionless);

$\mathrm{S}=$ Slope steepness factor (dimensionless);

$\mathrm{C}=$ Cover and management factor (dimensionless);

$\mathrm{P}=$ Conservation support practices factor (dimensionless).

The Conservation support practices factor $\mathrm{P}$ is the most unpredictable of the RUSLE factors, since site-specific conditions contribute to great variability in the erosion data, especially when related to severe storms (Yoder et al., 2001). For this reason, before applying the RUSLE model at a regional scale, in order to answer the RDP evaluation question a calibration of the model is needed to suit this model to local conditions (Hammad et al., 2004), especially when conservation practices are complex. To calibrate the RUSLE model, in particular to apply it to evaluate the effectiveness of CAP agri-environmental actions implemented by farmers, it is necessary to compare the predicted values against measured values in field, on a set of different case-study sites.

In the MO.NA.CO. project (see first page of this paper) the effectiveness of the GAEC cross-compliance standard 'temporary ditches to control erosion on sloping land' was determined in different farms by using the new UAV-GIS methodology and a comparison between RUSLE prediction vs. observed ones was done. The results are presented in another paper of this special issue of the Italian Journal of Agronomy (Bazzoffi et al., 2015). 


\section{UAV photogrammetry}

Among the techniques for measuring rill and interrill erosion (Douglas, 2001), photogrammetry from aerial pictures acquired through micro Unmanned Aerial Vehicles (UAV), integrated by post processing, is a promising methodology in terms of speed of data acquisition, degree of automation of data processing and cost-effectiveness.

The main advantage of micro drone UAV photogrammetry is the possibility of generation, at moderate costs, of high resolution Digital Elevation Models (DEMs) from stereo images taken near the soil surface by a high resolution camera. Furthermore, since the equipment (multirotor helicopter or micro aerial vehicle equipped with inertial measurement unit and GPS) is easy to acquire and manage, the user can schedule the flight plan autonomously and quickly decide the date of the flight when sunlight, weather and surface condition of the soil are the more favourable to produce high quality pictures suitable for measuring the studied variable and to generate a high quality DEM. On the contrary, the major limitation of this methodology consists of obtaining valid aerial pictures of the terrain surface when: i) vegetation and crop residues cover the soil; and ii) when the movement of shadows due to the lapsed time between adjacent aerial photo strips, changes the scene with consequent susceptibility to outliers as a reaction to shadow movement.

The former problem could be solved by vegetation filtering by near infrared images or by using the laser scanner technology LIDAR (Light detection and ranging) now transportable by multirotor drones and other unmanned vehicles. In any event, the effectiveness of LIDAR to produce a high quality DEM when the soil is covered by vegetation and plant residues depends on the quantity and distribution of the bare soil surface that still remains reachable by the laser beam. The problem of scene change due to shadow movement can be partly solved by performing, if possible, the UAV surveys when the sky is overcast with scattered light. Generally, a compromise has to be found between high resolution (fly at low altitude with lengthening of the time between photographic strips) and the susceptibility to outliers as a reaction to shadow movement. In any case it is recommended to place a high number of GCPs (Ground Control Points)on the soil surface, although it is time consuming (Rock et al., 2011).

It appears to be intuitive to measure soil erosion by a simple diachronic comparison of two DEM's representing the same surface respectively before and after soil erosion has occurred, on the assumption that the elevation of the soil surface would change only due to soil erosion. This assumption however is not always true and cannot be easily verified. A DEM modification can be determined also by other processes, with consequent masking effect of the elevation change due to erosion, in particular: i) by post-tillage consolidation of soil, which leads to a progressive increase of soil bulk density and consequently a general (and non-predictable in time and space) decrease of elevation of the surface; ii) by mass movements, as creeping and landslide; iii) by soil deformation due to shrink-swell of clay minerals in relation to soil moisture changes (Bronswijk, 1991; Brake et al., 2103).

Recently, Eltner et al. (2014) quantified rill and interrill erosion processes over a $600 \mathrm{~m}^{2}$ field plot areas by using multi-temporal DEMs obtained by using a UAV (octocopter equipped with high resolution camera) and a semi-automatic post-processing methodology to extract rills. This procedure entails a previous smoothing of the soil surface through a filter before applying the Canny operator (Canny, 1986) to extract the rill wall position. Afterwards, for each rill, width, depth, cross-section area of rills were automatically calculated for cross-sections with a sampling distance of $1 \mathrm{~cm}$. From these data the volume of the incisions over the soil surface was calculated. Nevertheless, this methodology is not easy to apply by no research users.

\section{Materials and methods}

\section{Drone and camera description}

The survey of rill erosion on the study areas was performed by using a mini electric UAV Octocopter, model Falcon 8 by Astec (Ascending technologies) as shown in Figure 1. The system is composed of an airplane with 8 electrical rotors in vertical takeoff and landing and a system of remote pilotage MGS (Mobile Ground Station). A control unit on-board of the flying vehicle manages the flight by using data from sensors (GPS, gyroscopes for attitude control and a barometer for the elevation relating to the ground) and interact with the mobile ground station to drive the vehicle over the planned waypoints. A proprietary Asctech software was used to program and manage the flight by connecting a laptop to the MGS. By remote control unmanned Falcon can fly autonomously, following pre-programmed paths and doing zenital shots at each waypoint, or the flight can be completely controlled by the user, assisted only by the stabilizer trim. The camera carried by Falcon 8 was a SONY NEX-5 (14.2 megapixel APS-C sensor, tilting of $+/-90^{\circ}$ ) actively compensated in pitch and roll axis. The Falcon 8 system comes with a ground remote control to operate the drone in conjunction with a PC that contains the flight plan.

\section{Ground Control Points and topographic survey}

Markers (Ground Control or Reference Points) are used to optimize camera positions and orientation data, which allows for better DEM reconstruction results. To generate accurate orthophotos at least $10-$ 15 ground control points (GCP) should be distributed evenly within the area of interest to be processed. In any event, by following the abovecited suggestion of Rock et al. 2011, it was preferred to place on the soil surface a high number of GCPs in order to achieve the iper- determination of stereo pairs for better accuracy.

GCP targets consisted of plastic sheets panels $(50 \times 50 \mathrm{~cm}) .0$ each panel, four square, black and white sectors, were drawn in a alternate cross pattern. At the centre of the panel a small hole was performed (drilled) to allow the exact positioning of the topographic pole during the GPS survey. The placement of GCPs was preceded by the definition of a square grid of points, over the georeferenced GoogleEarth image of the survey field, where to place evenly spaced targets. On field, with the help of a handheld rough GPS, GCPs targets were placed on the predefined

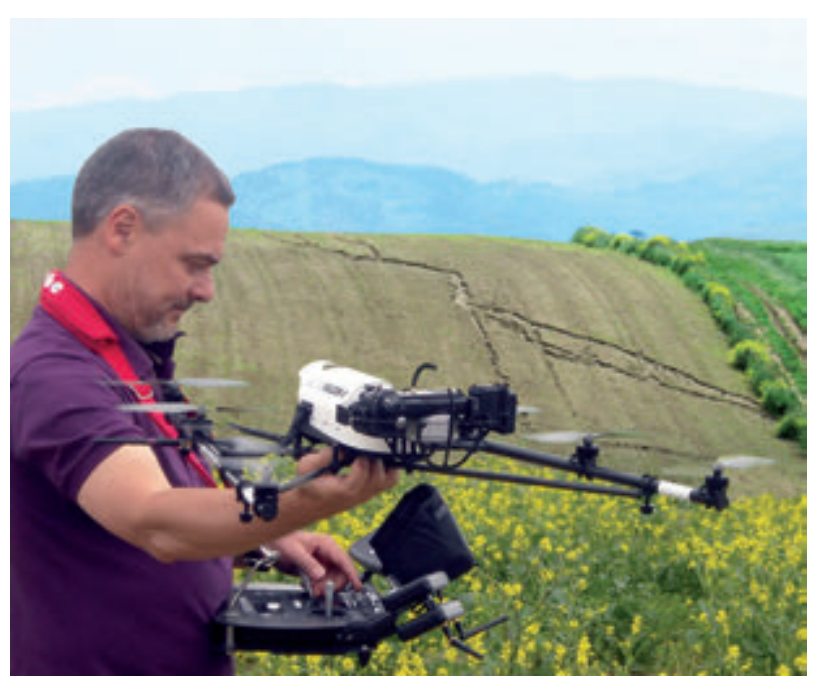

Figure 1. Falcon 8 Octocopter, and remote control station. In the background, a field rilled by soil erosion in one of the study areas of the MO.NA.CO. project. 
position of points. After placing the GCP markers their exact position was acquired with a topographic field survey by using a Leica GPS 1200 system (double-frequency, GPS/GLONASS) in RTK mode. It is known that accuracy of position and height of point measurement are dependent on many factors including number of satellites, geometry, observation time, ephemeris accuracy, ionosphere conditions, multipath etc.. RTK accuracies for the Leica GPS 1200 system stated by the manufacturer are: Horizontal (XY coordinates) $\pm 10 \mathrm{~mm}$, Height (Elevation) $\pm 20 \mathrm{~mm}$. GLONASS can increase accuracy by up to $30 \%$ relative to GPS only. Nevertheless, after processing 654 survey points through Leica Geo Office software (LG0), the statistical analysis of quality results revealed a better performance as opposed to the manufacturer's tolerance values. In fact, horizontal accuracy resulted in $\pm 0.869 \mathrm{~mm}$ for the $\mathrm{XY}$ coordinates and in $\pm 1.391 \mathrm{~mm}$ for elevation. Probably this good performance was due to very small distances between the base and rover antennas (maximum distance detected $234.2 \mathrm{~m}$ ).

For this kind of survey, unless there are special reasons, it is not strictly necessary to transform the local XYZ coordinates into the National Geodetic Network coordinate system. This way it is possible to save time and be operational shortly upon arriving at the site to be surveyed. The only care needed in order to repeat the survey in the future, if it becomes necessary, is to place the GPS base in correspondence of a permanent landmark located near the field to be measured, making it possible to reposition the base station on the same point and assign to it the same coordinate values detected in the previous survey.

In the present work GCP markers were georeferred by using the native GPS receiver coordinates, in the UTM-WGS84 geodetic system (ellissoidic elevations). In the video recognition of GCPs (post processing phase), for each marker the XYZ coordinates were assigned to the position of the hole in the centre of the panel.

\section{UAV image post-processing and DEM reconstruction}

Many image matching and surface reconstruction methods have been developed in recent years. On one hand they implement wellestablished techniques like Least Square Matching (Grün, 1985), and on the other innovative global and semi-global matching methods. Gross (2015) compared geometric accuracy, visual quality, ease of use and cost of three most popular image stitching software packages to create orthomosaics from the individual images: Photoscan Pro, Pix4D Pro Mapper and Microsoft Image Composite Editor for creating orthomosaics. Results suggested that Photoscan Pro and Pix4D Pro Mapper produced the best geometric accuracy, as measured by the root mean square error (RMSE) of real XY coordinates measured in field of a number of Ground Control Points compared to image derived coordinates. In addition, Photoscan Pro is significantly cheaper and ease to use than the other softwares.

From these considerations and with the goal of providing a low-cost methodology for measurement of rill erosion we used the Agisoft PhotoScan Pro commercial software, developed byAgisoft LLC company. Agisoft PhotoScan Pro has a very simple graphical user interface and it is able to perform both the orientation and the following dense stereo matching steps using a multi-image approach. Initially the software defines the images orientation and refines calibration camera parameters (the geometry of the images sequence allows to estimate a set of interior orientation parameters for each camera, should these have not been previously assigned); subsequently, it proceeds to the DEM generation. PhotoScan does not display the statistical results of the photogrammetric processing, for it is a sort of 'black-box' software. All the photogrammetric process is performed with a high level of automation and the user can decide the desired cloud density points density and the 3D modelling quality. The workflow is therefore extremely intuitive, being an ideal solution for less experienced users. Due to commercial reasons very little information about the algorithms used is available: some details can be recovered from the Photoscan User forum (http://www.agisoft.com/forum/index.php). Except for a 'Fast' reconstruction method, selectable by the user before the image matching process starts, that use a multi-view approach, the depth map calculation is performed pair-wise (probably using all the possible overlapping image pairs) and merging all the results into a single, final, 3D model. In fact, a multi-base line matching extension is more resilient against occlusion-detection and wrong matches, effecting the fusion of disparity of information given by all the match images and producing smoother results.

Table 1 shows the survey data produced by Agisoft PhotoScan Pro (post-processing reports) of the plots investigated in the framework of the MONACO project. This table is intended to help the user to reproduce the same experimental conditions to get similar results of the example exercises reported later in the text, by using the mean values of the 14 reports. It is important to state that, in the same table 1, the mean flying altitude has been calculated ex-post by Agisoft PhotoScan Pro, while in the field the UAV altitude was set equal to $30 \mathrm{~m}$ for all the surveys performed. This value is the altitude of the first waypoint of the AUV survey, starting from the most upstream part of the plot to be surveyed. The vehicle flies horizontally, so that the distance from the ground increases as it proceeds from upstream to downstream. For this reason the mean flying altitude calculated ex-post is always higher than the elevation imposed as initial flying parameter.

\section{Accuracy of DEM elevations}

The accuracy of elevation of the raster produced through the Falcon 8-PhotoScan system was determined by the statistical comparison (Student's $t$-test) of the mean elevation of 540 points detected respectively: i) by GPS field survey done on the occasion of one of UAV flights, and ii) by the Spatial Analyst tool 'Extract values to points' of ArcGis 10.0, where the input point feature defining the locations from which to extract the raster cell values is the shp-file contains the GPS-survey coordinates of the 540 points and the raster dataset whose values were extracted was the DEM produced by photoscan-pro software.

The results of this analysis are shown in Table 2. The mean difference, although statistically significant $(\mathrm{P}<0.01)$, resulted very limited $(-0.52 \mathrm{~cm})$ and the DEM produced by photoscan-pro software, in our experimental conditions can be considered effective for detecting rill incisions.

\section{The new UAV-GIS methodology}

To measure rill erosion occurred in a plot, regardless to sediment redeposition, the total volume of the incisions must be determined. To achieve this result, we assume that a channel cell has a negative plan curvature (Rana, 2006) and a non-channel cell has a zero or positive plan curvature. This way it is possible to find rill areas through curvature analysis. The methodology is based on two main analyses performed in ESri ArcGis 10.0 environment:

i) Plan Curvature analysis;

ii) Focal Statistics analysis.

In agricultural sloped land rills mainly develop on tractor wheel tracks and on linear soil depressions left by tillage. Thus, when soil erosion is slight, it would be impossible, through plan curvature analysis, to distinguish which part of a rill has been excavated by runoff water or is a residue of an incision or a track made respectively by tillage tools or wheel tractor passes. The optimal way to proceed in order to overcome this problem is to perform two UAV photo surveys, respectively before and after the rill has formed, then to apply the methodology by using the same calculation parameters on both DEMs and subtract the incision volume of DEM before-rill formation (false rill incisions due to tillage tools) from the after-rill volume of incisions (true rill). In any 
event, diachronic analysis of multiple consecutive DEMs can be used to evaluate the increase of rill erosion in consecutive observation periods. When rill erosion is sufficiently pronounced to cancel false rills, so that their influence on rill erosion calculation can be considered negligible, the UAV-GIS methodology can be applied on the after-rill DEM only. The proposed UAV-GIS methodology is not intended for the measurement of interrill erosion (sheet erosion) because this process does not determine surfaces affected by negative plan curvature. Interrill erosion can be estimated from the calculated value of rill erosion, according to McCool et al. (1989). A solved exercise to assess interrill erosion is reported later in the text.

Two case study are presented, solved step by step, in order to help the user to overcome possible difficulties of interpretation in the application of the GIS procedure. The first solved exercise concerns a heavily eroded plot where only one DEM was used to calculate rill erosion. The second exercise has as its object that of a not heavily rilled plot where the diachronic analysis of DEMs, described above, was considered necessary to get rid of false rill influence on soil erosion measurement. In this case rill erosion increased the volume of pre-existing mechanical incisions which are still distinguishable (by the naked eye on field) from the incision-forms due to runoff water. Plan curvature analysis and Focal Statistics analysis are described in detail, as they are the essential constituents of the new methodology. The comparison between UAV-GIS measured and RUSLE predicted erosion rates is also reported.

\section{Plan Curvature Analysis to identify rills}

Plan Curvature Analysis of DEM allows us to identify the cells of the DEM that belong to rill areas. As reported by Kimerling et al. (2011), Planform Curvature (commonly called plan curvature) is the second derivative of the surface, or the slope-of-the-slope, perpendicular to the direction of the maximum slope and reveals the convergence and divergence of flow across the surface (Figure 2). Convex cells have positive value of Plan curvature and the soil surface is sidewardly convex at that cell. On the contrary, concave cells have positive values and the surface is sidewardly concave at that cell. A value of zero indicates that the surface is flat. By performing the Curvature analysis of the DEM, the resulting Plan curvature raster includes negative (concavities) and positive (convexities) values. The user must decide the proper negative threshold value above which the raster values do not identify rill forms. In fact, not all negative Plan curvature cells are 'organized' in such a way to define a rill. Especially when a DEM has a very small cell size (produced by post processing low-altitude stereo photos) detail is

\section{No Rill Rill}
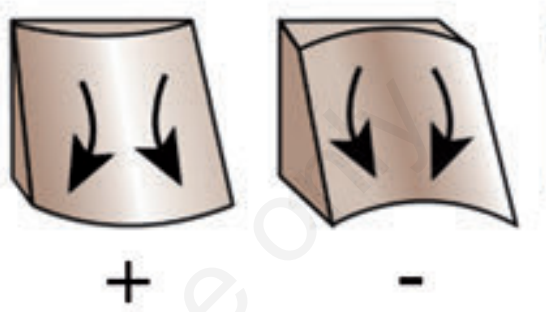

No Rill

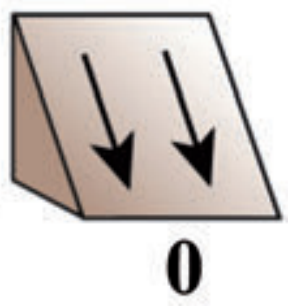

Figure 2. Plan curvature is perpendicular to the slope and affects the convergence and divergence of flow across the surface (modified from Kimerling et al., 2011). Rills are characterized by negative Plan curve values.

Table 1. Survey data produced as post-processing reports by Agisoft PhotoScan Pro.

\begin{tabular}{|c|c|c|c|c|c|c|c|c|}
\hline $\begin{array}{l}\text { Agisoft Photo } \\
\text { Scan Pro Reports }\end{array}$ & $\begin{array}{l}\text { Coverage } \\
\text { (ha) }\end{array}$ & $\begin{array}{c}\text { Images } \\
\text { (n) }\end{array}$ & $\begin{array}{l}\text { Images } \\
\text { (n/ha) }\end{array}$ & $\begin{array}{l}\text { Ground Control } \\
\text { Points GCP (n) }\end{array}$ & $\begin{array}{l}\text { Mean flying } \\
\text { altitude (m) }\end{array}$ & $\begin{array}{l}\text { GCP density } \\
\text { (n.GCP/ha) }\end{array}$ & $\begin{array}{l}\text { Photomosaic } \\
\text { resolution ( } \mathrm{m} / \mathrm{pix})\end{array}$ & $\begin{array}{l}\text { DEM resolution } \\
\text { (m/pix) }\end{array}$ \\
\hline Report 1 & 1.074 & 56 & 52.14 & 27 & 42.80 & 25.15 & 0.01009 & 0.0486 \\
\hline Report 2 & 8.892 & 321 & 36.10 & 61 & 44.51 & 6.86 & 0.01137 & 0.0257 \\
\hline Report 3 & 1.165 & 80 & 68.67 & 26 & 40.53 & 22.31 & 0.00916 & 0.0463 \\
\hline Report 4 & 1.699 & 103 & 60.62 & 31 & 49.97 & 18.25 & 0.01132 & 0.0572 \\
\hline Report 5 & 1.056 & 51 & 48.30 & 27 & 45.74 & 25.57 & 0.01161 & 0.0538 \\
\hline Report 6 & 1.074 & 56 & 52.14 & 25 & 42.15 & 23.27 & 0.01004 & 0.0487 \\
\hline Report 7 & 1.645 & 98 & 59.57 & 39 & 47.47 & 23.71 & 0.01163 & 0.0550 \\
\hline Report 8 & 1.027 & 25 & 24.34 & 12 & 47.75 & 11.69 & 0.01276 & 0.0555 \\
\hline Report 9 & 1.764 & 72 & 40.82 & 29 & 48.86 & 16.44 & 0.01194 & 0.0567 \\
\hline Report 10 & 3.704 & 93 & 25.11 & 22 & 41.97 & 5.94 & 0.01047 & 0.0479 \\
\hline Report 11 & 1.637 & 36 & 21.99 & 66 & 40.26 & 40.31 & 0.01085 & 0.0425 \\
\hline Report 12 & 0.960 & 66 & 68.75 & 66 & 55.96 & 68.72 & 0.01303 & 0.0279 \\
\hline Report 13 & 1.453 & 77 & 52.99 & 69 & 44.51 & 47.49 & 0.01143 & 0.0257 \\
\hline Report 14 & 0.234 & 13 & 55.56 & 23 & 38.90 & 98.17 & 0.01115 & 0.0115 \\
\hline Mean & 1.956 & 81.929 & 47.65 & 37.36 & 45.10 & 30.99 & 0.011 & 0.043 \\
\hline Standard deviation & 2.140 & 73.779 & 15.74 & 19.41 & 4.610 & 25.58 & 0.001 & 0.0145 \\
\hline Conf. $( \pm 95 \%)$ & 1.531 & 52.78 & 9.09 & 13.9 & 3.30 & 18.30 & 0.00075 & 0.0104 \\
\hline
\end{tabular}

Table 2. Comparison of raster value elevations versus field-survey values detected by geodetic GPS.

\begin{tabular}{|c|c|c|c|c|c|c|c|c|c|}
\hline & Mean elevation & SD & $\mathbf{N}$ & Diff. & SD diff. & $\mathrm{t}$ & df & p & P Levene \\
\hline GPS-survey & 246.5474 & 4.107308 & 540 & \multirow{2}{*}{-0.00525} & \multirow{2}{*}{0.039758} & \multirow{2}{*}{-3.06818} & \multirow{2}{*}{539} & \multirow{2}{*}{$0.0023^{* *}$} & \multirow{2}{*}{0.952} \\
\hline Raster value & 246.5526 & 4.116980 & 540 & & & & & & \\
\hline
\end{tabular}


so fine that a large number of sparse negative cells generate confusion and the image of the Plan Curvature raster is not easily interpretable. The choice of the negative threshold value to identify rills can be performed by using in turn different thresholds followed by the close-up observation of the negative curvature cells overlapped both to the orthophoto and to different hillshade rasters derived from DEM (by using different azimuth and altitudes). The observation of the flow accumulation raster can also help; observing the flow accumulation raster can also be of assistance. A proper 'natural' criterion to decide if the selected threshold is effective to highlight the majority of rills is that of observing the convergence of micro-rills into major rills. A feeble incision defined by a negative plan curvature threshold can be considered to be a rill when it is surrounded by other similar forms that converge all together in a larger and well defined rill.

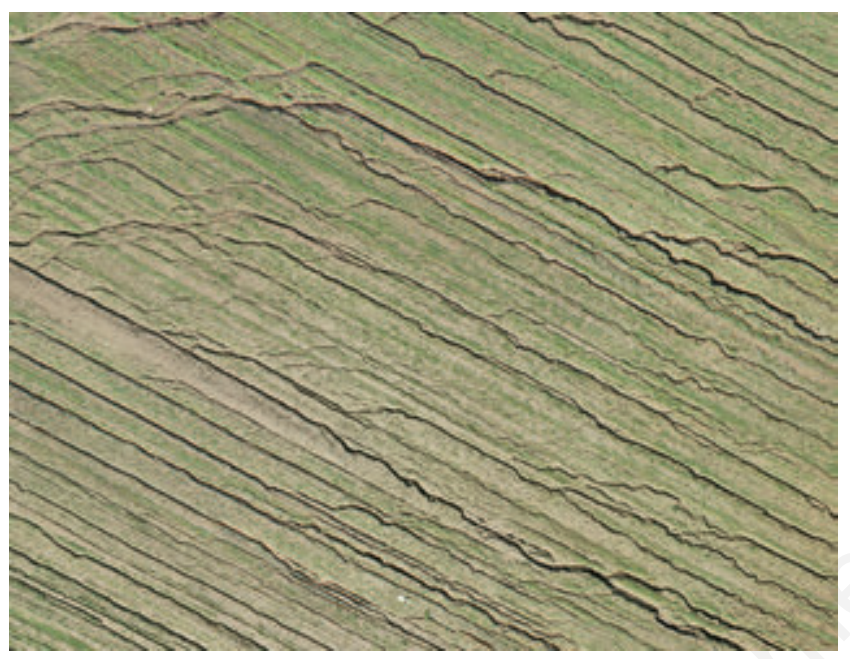

Figure 3. Orthophoto of a portion of a rilled surface (taken from the plot analysed in exercise 1).

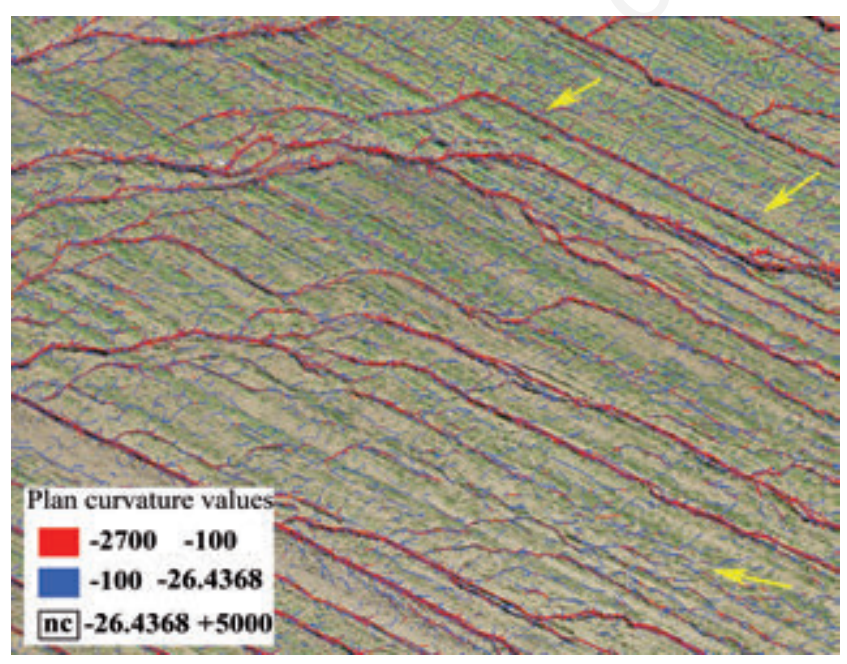

Figure 4. PlanCurv cells $\leq-26.4368$ (curvature threshold chosen). This value was considered the best compromise to detect most of the rills. Microrills are represented in blue. Yellow arrows show the convergence of microrill into major rills. PlanCurve values >-26.4368 did not evidence incision coherent with runoff dynamics and were not represented (nc).
Anyway, it is evident that the choice of a threshold could determine the exclusion from calculation of some very small rills. In Figure 3 a small portion of the orthophoto mosaic of the rilled plot analysed in exercise 1 is reported. In Figure 4 an example of definition of the Plan Curvature threshold for a close up view of the same piece of land is reported.

\section{Focal Statistics to determine rill depth}

After Plan Curvature Analysis, Focal Statistics analysis must be performed. This analysis calculates for each input cell of the elevation raster (DEM) a statistic parameter of the values within a neighbouring form around it. In our procedure we determine, for each rill cell, the Maximum value of elevation encountered among the DEM pixels belonging to a neighbouring circle surrounding the cell. For each rill point the circular neighbouring form is intended to calculate the difference between the elevation of the rill rim and the elevation of the point. This difference is assumed as the depth of the rill in the specific point position. To better explain the principle of operation of the analysis we show in Figure 5 a typical manual field survey of the depth of a rill in a given position. In the figure, the reference bar is placed between the two rill rims and defines the mean elevation between the two rims. The tape measurement of the difference of elevation between the bar and the rill surface is the rill depth in that position. With the use of Focal Statistics by circles we intend to reproduce in an automated manner a similar mode of operation, with some simplification and assumptions as shown in Figure 6 . The circle around a given point position inside a rill intercepts a number of cells of the elevation raster (DEM). The maximum elevation found by Focal Statistics in the neighbouring circle is assumed as the elevation of the rill rim. By subtracting the elevation of rill point from the rill rim elevation the depth of rill is determined in the same rill point position. In the text which follows this analysis is called 'FocalDiff' analysis.

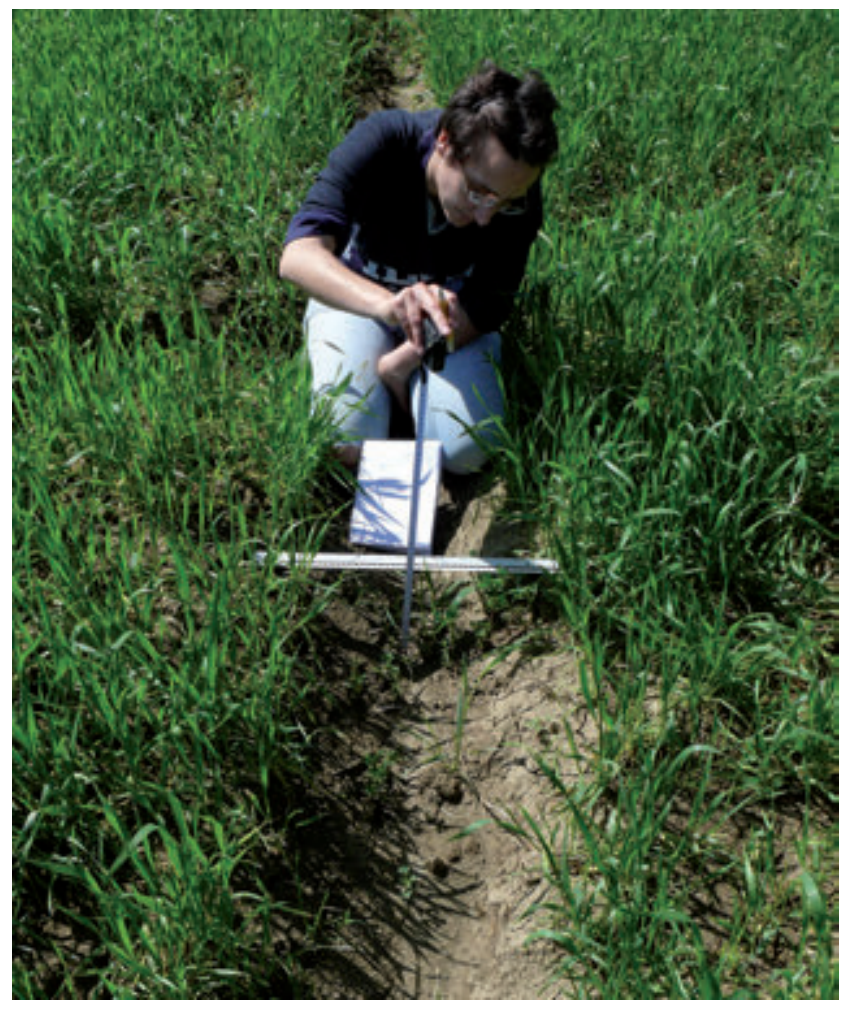

Figure 5. Typical field survey of a rill depth in a given rill point position. The horizontal bar defines the rim elevation. 
Respect to manual operating mode the reference bar is simplified by a horizontal segment which connects the rim point having the maximum elevation to the centre of circle (the centre corresponds to the projection of the rill point on the circle). Different from the manual positioning of the bar, the segment do not connect the two opposite rims perpendicularly to them. Another simplification is that the elevation of one rim only is considered instead of interpolating between the two elevations of opposing rims. In Figure 7 it is shown a $30 \mathrm{~cm}$ circle with the elevation value of a rill point in the centre of the circle and the maximum value (rill rim elevation) detected through Focal Statistics. The length of the radius of the circle is of crucial importance. In fact, for each rill point, the neighbouring circle must be large enough to intercept an area beyond at least one of the rill rim. At the same time, the circle must be sufficiently small not to intercept a too large area beyond the rim. Too large of a circle would lead to a negative repercussion on the calculation of the rill depth, which could result as increased in respect to reality by the influence of the local slope gradient.

The Plan curvature value associated to each rill point helps the user in the choice of the proper radius length to be used. This can be easily explained by the example shown in Figure 8, regarding a portion of the plot analysed in exercise n.1. In this figure rill points have been overlapped to the orthophoto. Points were separated in 3 groups of different colours according to different ranges of Plan curvatures values. The yellow group of points, with plan curvature values spanning -60 26.436832 , is able to satisfactorily intercept very small rills. The same group includes rill points of large rills which are very close to rill rims. For these points, we decided to consider the depths calculated by the 15

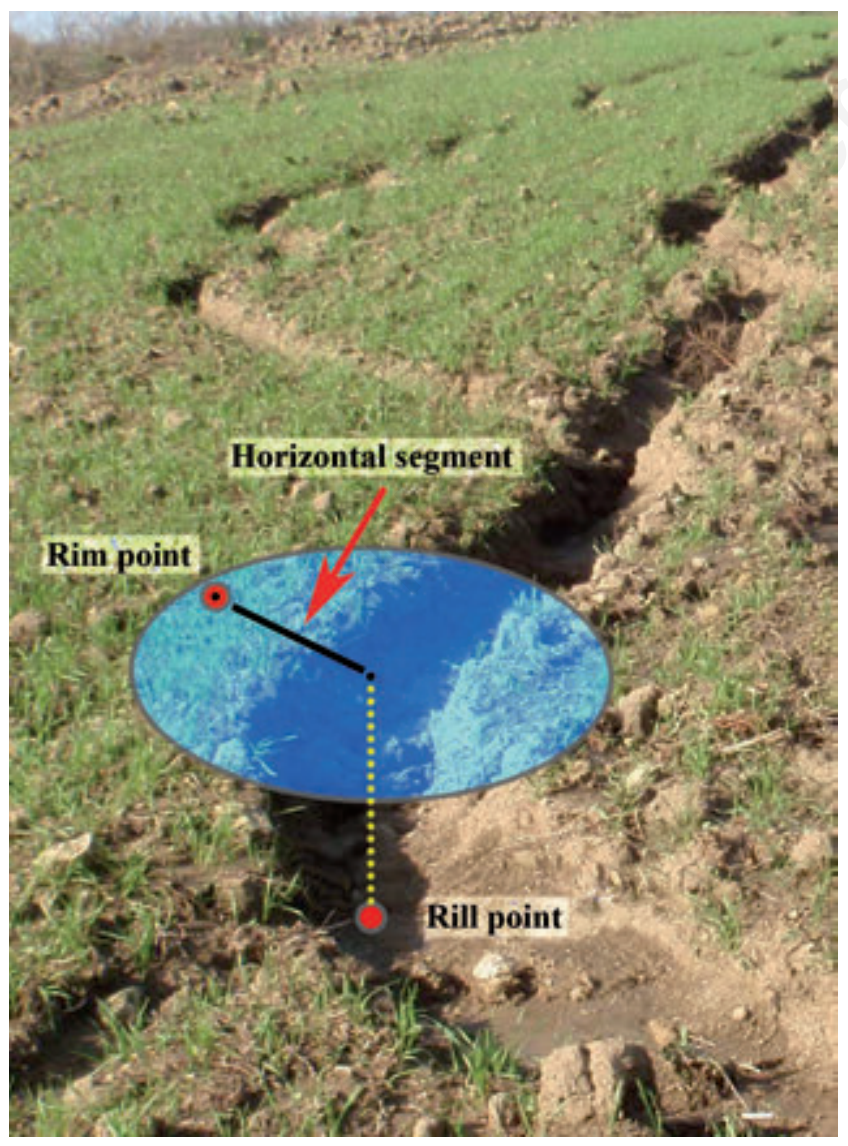

Figure 6. Example of a circular buffer around a given rill point. The maximum elevation found in the buffer is assumed as the rill rim elevation.

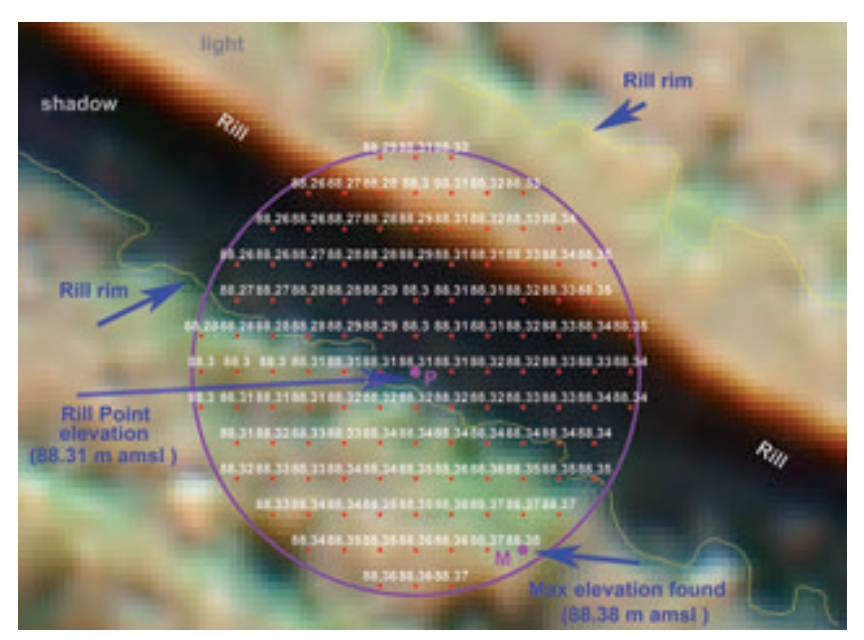

Figure 7. Representation of a 30-cm neighbouring circle around a rill point ' $P$ ' (with elevation $88.31 \mathrm{~m}$ asl). The Focal statistics analysis detected the maximum elevation value $88.38 \mathrm{~m}$ (asl) inside the circle (position ' $M$ ' in the figure). This value is assumed as the rim elevation. The elevation difference $M$ minus $P$ is the depth of rill in the $P$ position.

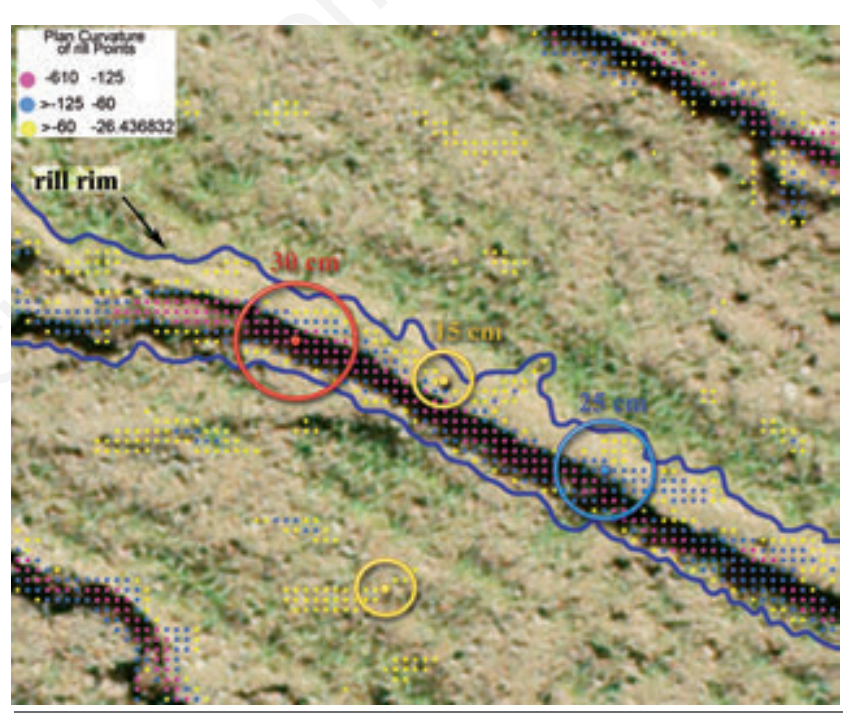

Figure 8. The Plan curvature value associated to each rill point allows the user the choice of the proper radius length to be used to calculate rill depth.

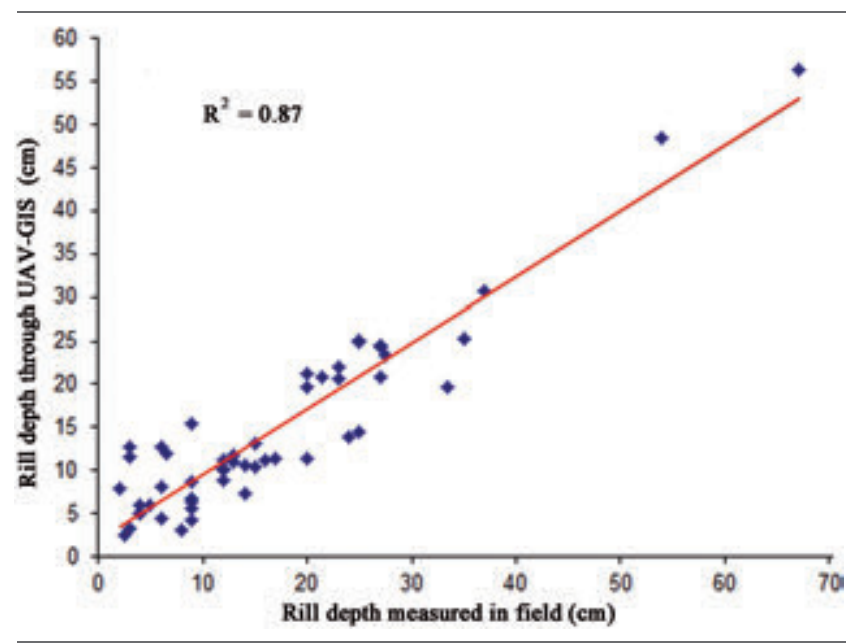

Figure 9. Regressions of UAV-GIS rill depths (obtained by using $30-\mathrm{cm}$ radius in Focal Stats. ) vs. in field measured depths. 
cm radius as the most appropriate. In fact the rim is very close to these rill points. The magenta group of points, having plan curvature values spanning $-610-125$, is able to intercept rill points in the deepest position of large rills. For these points, we decided to consider the depths calculated by the $30 \mathrm{~cm}$ radius as these points are the most distant from the rill rims.The cyan group of points, with plan curvature values spanning $-125-60$, includes rill points in between the two previous categories, therefore we decided to consider the depths calculated by the 25 $\mathrm{cm}$ radius.

This operation is particularly needed when on the rilled surface a variety of wide-to-narrow rills are present. If rills are roughly onedimensional only a radius length can be selected. Should the study plot be differentiable into sub-zones of prevailing rill widths (e.g., very small rills uphill, very large rills or gullies downhill ) the analysis can be performed separately for each of them, by applying different radius lengths of neighbouring circles in relation to the prevailing rill dimension. Then sum up the zone results. However, for the two plots of exercise 1 and 2 reported later in text, we have not deemed it necessary to carry out the analysis by sub-zones. Total volume of rill erosion $\left(\mathrm{m}^{3}\right)$ can be calculated through the simple formula as follows:

$$
\mathrm{V}=\sum_{1}^{n} \mathrm{~A} \cdot \mathrm{H}
$$

where:

$\mathrm{n}=$ number of groups of rill points according to different ranges of Plan curvatures values;

$\mathrm{A}=$ total area of rill cells of DEM $\left(\mathrm{m}^{2}\right)$ in each group;

$\mathrm{H}=$ mean depth $(\mathrm{m})$ of rill points in each group.
The total area of rill (A) in each group is calculated by multiplying the number of DEM cells (or points) belonging to rills by the cell area. Mean depth $(\mathrm{H})$ of rill points in each group is the mean value of differences of rim elevation minus rill point elevation, as determined through Focal Statistics analysis. Total rill erosion as weight $(\mathrm{t})$ in the study plot can be calculated by multiplying the sum of rill volumes $\left(\mathrm{m}^{3}\right)$ of groups by soil bulk density at AUV-survey time $\left(\mathrm{t} \mathrm{m}^{-3}\right)$. Specific rill erosion (t/ha) is obtained by dividing the total rill erosion ( $\mathrm{t}$ ) by the plot are (ha). Bulk density of soil must be determined by core-method survey in field (mean value of samples taken close to rill rims, representative of the entire plot under study).

\section{Calibration of the UAV-GIS methodology}

To determine the effectiveness and reliability of the new methodology a comparison between rill depth measured in field and depth measured by UAV-GIS analysis was done. Depths of 51 rill points were measured in the field by hand through horizontal bar and a metal rule (Figure 5) and georeferred by the use of RTK-GPS. Within a single rill we did not measure more than a single point. Where points were measured is a heavily-rilled field (18.6 ha) at Tor Mancina (Rome) which includes the plot in exercise n.1 reported below. Measurements in field were made simultaneously to the UAV-GIS survey. In Table 3 the results of five linear regressions are shown, according to 5 different radius size of the neighbourhood circle used in UAV-GIS analyses.

Table 3. Regressions of UAV-GIS rill depths $v s$. in field measured depths.

\begin{tabular}{|c|c|c|c|c|c|c|c|}
\hline \multirow[t]{2}{*}{ Eq. } & \multirow[t]{2}{*}{ Focal Statistic Radius cm } & \multirow[t]{2}{*}{ Regression $\mathrm{R}^{2}$} & \multirow[t]{2}{*}{$\mathrm{F}(1.49)$} & \multirow[t]{2}{*}{ P-level Regress } & \multicolumn{2}{|c|}{ B coefficients } & \multirow[t]{2}{*}{ St.Err.Est } \\
\hline & & & & & Intercept & X & \\
\hline 1 & 10 & 0.837 & 251.99 & 0.000000 & -0.1977 & 0.6047 & 5.28 \\
\hline 2 & 15 & 0.852 & 282.55 & 0.000000 & 0.3437 & 0.6415 & 5.03 \\
\hline 3 & 20 & 0.867 & 318.91 & 0.000000 & 0.8815 & 0.6792 & 4.77 \\
\hline 4 & 25 & 0.871 & 331.22 & 0.000000 & 1.3949 & 0.7349 & 4.70 \\
\hline 5 & 30 & 0.873 & 336.72 & 0.000000 & 1.9886 & 0.7594 & 4.67 \\
\hline
\end{tabular}

Table 4. Agreement between infield measured depths, grouped by ranges, and UAV-GIS depths obtained by using neighbouring circles of different radii.

\begin{tabular}{|c|c|c|c|}
\hline Rill depth range $(\mathrm{cm})$ & Method & Mean depth (cm) & Mean separation (Duncan test) \\
\hline $0-5$ & $\begin{array}{l}\text { Field survey } \\
\text { UAV-GIS } 10 \mathrm{~cm} \text { radius }\end{array}$ & $\begin{array}{l}3.39 \\
3.43\end{array}$ & $\begin{array}{l}\mathrm{A} \\
\mathrm{A}\end{array}$ \\
\hline $6-10$ & $\begin{array}{l}\text { Field survey } \\
\text { UAV-GIS } 30 \mathrm{~cm} \text { radius }\end{array}$ & $\begin{array}{l}8.21 \\
8.21\end{array}$ & $\begin{array}{l}\text { B } \\
\text { B }\end{array}$ \\
\hline $11-15$ & $\begin{array}{l}\text { Field survey } \\
\text { UAV-GIS } 30 \mathrm{~cm} \text { radius }\end{array}$ & $\begin{array}{l}13.33 \\
10.39\end{array}$ & $\begin{array}{l}\mathrm{C} \\
\mathrm{C}\end{array}$ \\
\hline $16-20$ & $\begin{array}{l}\text { Field survey } \\
\text { UAV-GIS } 30 \mathrm{~cm} \text { radius }\end{array}$ & $\begin{array}{l}18.60 \\
14.97\end{array}$ & $\begin{array}{l}\text { D } \\
\text { D }\end{array}$ \\
\hline $21-25$ & $\begin{array}{l}\text { Field survey } \\
\text { UAV-GIS } 30 \mathrm{~cm} \text { radius }\end{array}$ & $\begin{array}{l}23.79 \\
20.24\end{array}$ & $\begin{array}{l}E \\
E\end{array}$ \\
\hline $26-30$ & $\begin{array}{l}\text { Field survey } \\
\text { UAV-GIS } 30 \mathrm{~cm} \text { radius }\end{array}$ & $\begin{array}{l}27.13 \\
23.24\end{array}$ & $\begin{array}{l}F \\
F\end{array}$ \\
\hline $31-35$ & $\begin{array}{l}\text { Field survey } \\
\text { UAV-GIS } 30 \mathrm{~cm} \text { radius }\end{array}$ & $\begin{array}{l}35.17 \\
30.22\end{array}$ & $\begin{array}{l}\mathrm{G} \\
\mathrm{G}\end{array}$ \\
\hline $36-70$ & $\begin{array}{l}\text { Field survey } \\
\text { UAV-GIS } 30 \mathrm{~cm} \text { radius }\end{array}$ & $\begin{array}{l}60.50 \\
58.44\end{array}$ & $\begin{array}{l}\mathrm{H} \\
\mathrm{H}\end{array}$ \\
\hline
\end{tabular}


The 5 Regression equations are as follows:

$$
\mathrm{y}=\mathrm{UG}_{\mathrm{depth}} \cdot \mathrm{X}+\text { Intercept }
$$

where:

$\mathrm{UG}_{\text {depth }}=$ rill depth $(\mathrm{cm})$ calculated by UAV-GIS analysis;

$\mathrm{X}$ and intercept coefficients are reported in Table 3 .

All equations resulted highly significant with very high $\mathrm{R}^{2}$ coefficients. The best is equation n. 5 (Figure 9), which was obtained through UAV-GIS depth values derived by using 30 radius in Focal statistics. Table 4 shows the agreement between infield measured depths, grouped by ranges, and UAV-GIS depths obtained by using neighbouring circles of different radius. In the same table only the best agreement are reported, while worst mean depths obtained by using all other radius lengths were omitted. It is apparent that $10-\mathrm{cm}$ radius was the best length only for the $0-5 \mathrm{~cm}$ rill depth range. For all other ranges of rill depths the best radius length resulted $30 \mathrm{~cm}$. Table 5 shows the separation by Duncan test of mean rill depths by different radius length.

In general, from results it can be said that the UAV-GIS methodology can be used to detect rill depth, taking care to use the appropriate radius length in the Focal statistics analysis.

\section{Step by step description of ESRI ARCGIS pro- cedure for detecting rill erosion}

\author{
Note: File names are only examples. Full Path for folders and files are
} omitted.

\section{EXERCISE N.1 (Tor Mancina, Rome)}

Severely eroded field (Figure 10). Only one DEM (after erosion) analysed.

\section{Site description}

WGS84 Coordinates of plot centroid: N $42^{\circ} 05^{\prime} 41.70^{\prime}$; E $12^{\circ} 37^{\prime}$ 58.29 '.

Type: Basin

Area: 1.5776 ha

Mean Slope: $15.4 \%$

Maximum length along the slope gradient: $136.1 \mathrm{~m}$

Geology: Pedogenized stratified volcanic tuffs with lapilli, cinerites and Pleistocene leucitic scorias.

Soil classification: Typic Argixeroll (Soil Survey Staff, 2014), Clay loam texture (USDA, 2015).

Grain size distribution: Total Sand 39.3\%, Total Silt 30.0\%, Clay $30.7 \%$, 0.M. 1.61\%.

Bulk density at UAV survey time: $1.247 \mathrm{t} / \mathrm{m}^{3}$

\section{UAV-Survey conditions and DEM resolution}

Mean flying altitude (m): 41.97

GCP spacing: on a square grid $40 \times 40 \mathrm{~m}$

Photomosaic resolution (m/pix): 0.01047

DEM resolution (m/pix): 0.0479437

In Figure 11 the orthomosaic of the study plot is reported

\section{STEP 1: extract DEM by plot mask}

Extract the portion of DEM corresponding to the plot on which to measure rill erosion, by using the shpfile of the plot polygon as feature mask data. In Figure 12 the shadowed DEM is shown.

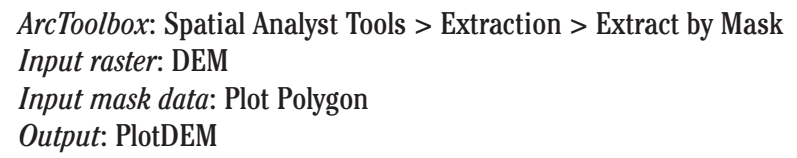

\section{STEP 2: DEM smoothing}

Perform a smoothing (Low pass) on the plot DEM. This filter traverses a low pass 3-by-3 filter over the raster by calculating the average (mean) value for each $3 \times 3$ neighborhood.

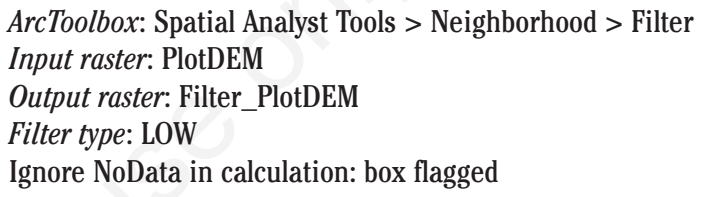

STEP 3: Planar Curvature

Produce the Plan curvature raster of PlotDEM

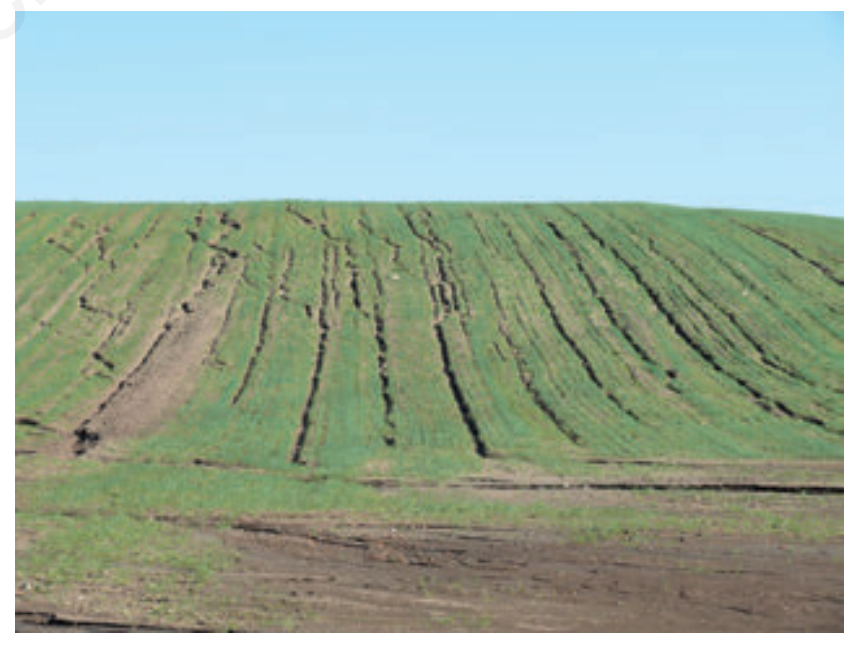

Figure 10. In the study plot at Tor Mancina the surface is characterised by heavy soil erosion.

Table 5. Separation by Duncan test of mean rill depths by different radius lengths used in UAV-GIS analysis.

\begin{tabular}{|c|c|c|c|c|}
\hline Method & Mean rill depth & 1 & 2 & 3 \\
\hline UAV-GIS $10 \mathrm{~cm}$ radius & 9.80 & $* * * *$ & & \\
\hline UAV-GIS $15 \mathrm{~cm}$ radius & 10.95 & $* * * *$ & $* * * *$ & \\
\hline UAV-GIS $20 \mathrm{~cm}$ radius & 12.12 & $* * * *$ & $* * * *$ & \\
\hline UAV-GIS $25 \mathrm{~cm}$ radius & 13.55 & $* * * *$ & $* * * *$ & $* * * *$ \\
\hline UAV-GIS $30 \mathrm{~cm}$ radius & 14.55 & & $* * * *$ & $* * * *$ \\
\hline Field survey & 16.54 & & & $* * * *$ \\
\hline
\end{tabular}


ArcToolbox: Spatial Analyst Tools $>$ Surface $>$ Curvature Input raster: PlotDEM

Output curvature raster: any name (this raster is not required in subsequent analyses)

Z factor: 1

Output profile curve raster: any name (this raster is not required in subsequent analyses)

Output plan curve raster: $\mathrm{PICu}$ _Plot

Filter type: LOW

Ignore NoData in calculation: box flagged

\section{STEP 4: Planar-Curvature threshold selection to identify rills}

This step has been explained in the chapter: 'Plan curvature Analysis to identify rills'.

Figure 13 shows the result of the rill extraction.

Output: TresholdValue

\section{STEP 5: Raster calculator (to select pixels belonging to rills)}

The selected DEM cell belonging to rills, as detected through the previous PlanCurv analysis, are extracted from DEM and converted into a raster.

Through the Map Algebra tool the value 1 is assigned to rill cells, while 'Null' (no data) is assigned to no-rill cell. The output raster is used in the following step as 'multiplier raster' (Figure 14).

ArcToolbox: Spatial Analyst Tools > Map Algebra > Raster Calculator Tools: Conditional > Con

Expression: Con('PICu_Plot', 'PICu_Plot'/PICu_Plot',','VALUE $\leq$ Threshold value')

Thershod Value: User choice (in our exercise the selected value was -26.4368)

\section{Output raster: PlanCurvRill}

STEP 6: Assigning the elevation value to pixels belonging to rills

The raster of elevation values for rill cells only is obtained by multiplying the DEM by the 'multiplier raster' of Step 5 . Where the cells value of this raster is 1 the result of multiplication is equal to the DEM value. 0 n $<$ null $>$ cells no elevation value is assigned to the output raster and $<$ null $>$ result is assigned to cells.

ArcToolbox: Spatial Analyst Tools > Map Algebra > Raster Calculator Expression: 'PlotDEM' * 'PlanCurvRill'

Output raster: Rill_Elev

STEP 7: Conversion of pixels belonging to rills into a Point shpfile

The raster with elevation values on rill cells is now converted into a point shpfile.

The resulting table is reported as example in Figure 15. The visual representation of rill points of the shpfile is shown in Figure 16.

ArcToolbox: Spatial Analyst Tools > Conversion Tools > From Raster $>$ Raster to Point

Input raster: Rill_Elev

Field: Value

Output point features: Rill_Elev_Points

\section{STEP 8: Focal Statistics on DEM}

Focal Statistics calculates for each input cell location of DEM a selected statistic parameter of the values within a specified neighbourhood around it. In this analysis the maximum value of DEM within a neighborhood circle around each rill cell is determined.

This analysis must be repeated several times according to the number of different radius sizes selected by the user. We performed six analyses for the following radius sizes: $10 \mathrm{~cm}, 15 \mathrm{~cm}, 20 \mathrm{~cm}, 25 \mathrm{~cm}, 30$

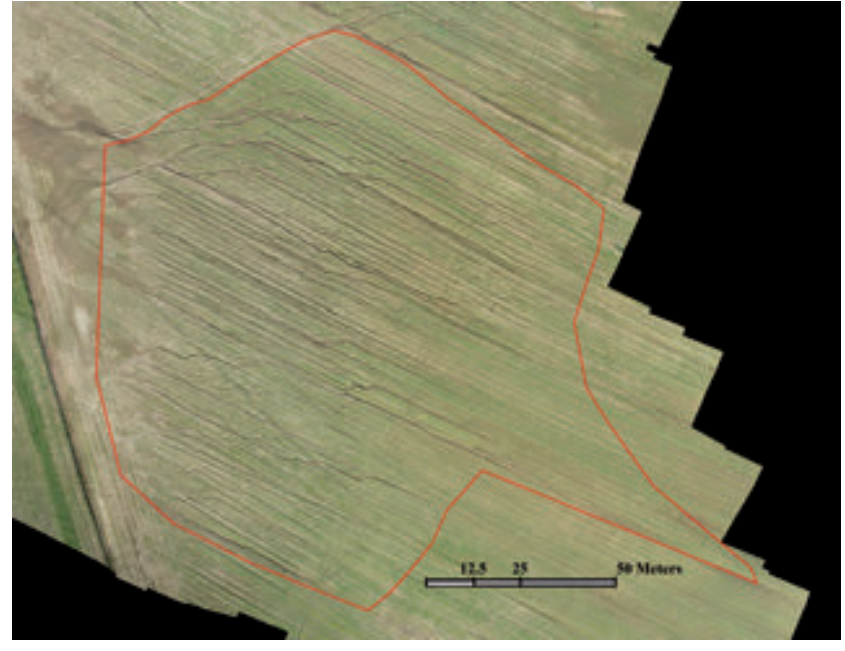

Figure 11. The plot at Tor Mancina of the example exercise n. 1.

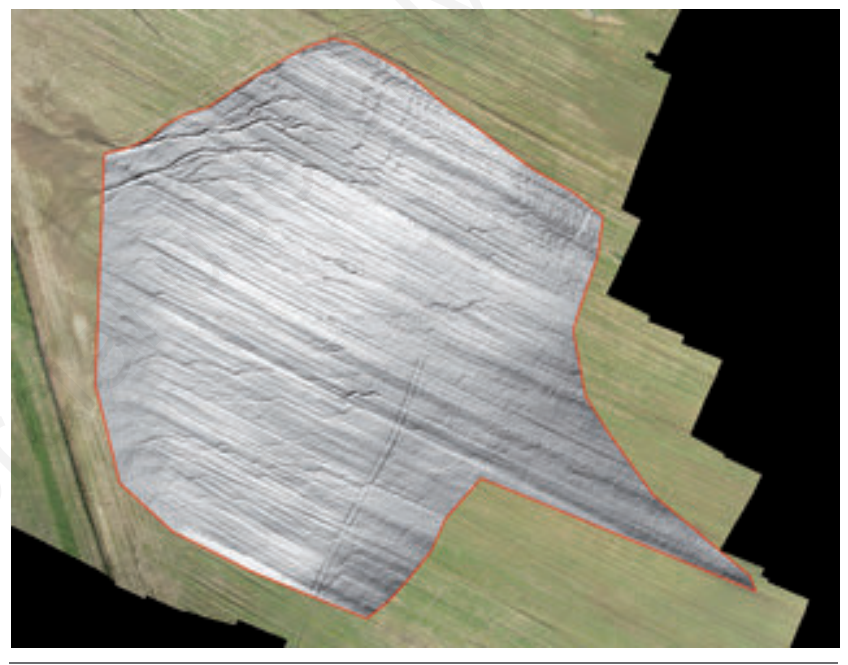

Figure 12. The shadow of DEM shows that rills started developing along tractor wheel tracks and other linear soil depressions left by tillage.

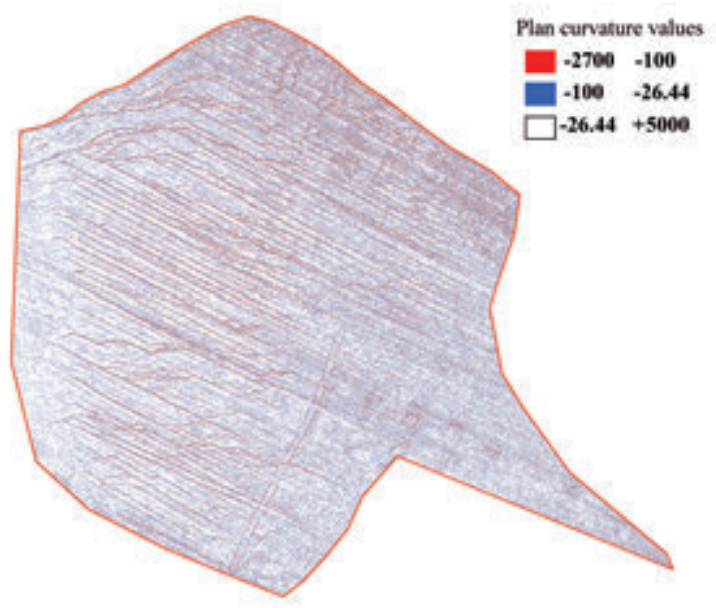

Figure 13. The result of rill extraction by selecting the appropriate threshold of Plan curvature value (major rills evidenced in red, small rill in blue). 
$\mathrm{cm}$. The maximum radius size was $30 \mathrm{~cm}$ because the maximum rill width observed on the orthophoto was about $50 \mathrm{~cm}$.

ArcToolbox: Spatial Analyst Tools > Neighborhood > Focal Statistics Input raster: PlotDEM

Output raster: FocalPlotDEM

Neighborhood: Circle

Neighborhood Settings Radius: length in map units

Neighborhood Settings Units: Map

Statistics type: Maximum

Ignore NoData in calculation: box flagged

\section{STEP 9 Extraction of Focal Statistics values to Rill points}

As said in Stp 7, the table of the shpfile 'Rill_Elev_Points' (see step 7) reports in the 'grid code' field the elevation value of rill cells. This shpfile must be added by a new field containing the maximum value of DEM found by Focal Statistics in the circle around each rill point. This operation is performed by using the command 'Extracts values to Point'.

The resulting shpfile table contains, for each rill point, a field with the elevation value derived from DEM and another field with the Maximum elevation value found in the neighbouring circle.

If the extraction to points operation returns <null> values, export the shpfile Rill_Elev_Points in a new shpfile and delete fields to the right of the 'pointid' field. Then use this shpfile for all extractions. Deleted fields can be joined at the end of extractions.

ArcToolbox: Spatial Analyst Tools > Extraction > Extract Values to Points

Input Point Features: Rill_Elev_Points

Input raster: FocalPlotDEM

Output point features: RillPoints_Elev_Max

Interpolate values at the point locations: box not flagged

Append all the input raster attributes to the output point features: box flagged

\section{STEP 10: Mean rill excavation depth}

The shpfile RillPoints_Elev_Max is used to calculate the mean excavation depth of rills. To do this, a new field named 'Difference' must be added to its table.

The Attribute Table of this shpfile (Figure 17) shows in the field named 'grid_code' the elevation of rill points, while in the field 'RASTERVALU' the maximum DEM value in the circle surrounding each point is shown (rill rim elevations).

The newly created 'Difference' field is used to calculate the difference 'RASTERVALU' minus 'grid_code', which gives the rill excavation depths at the point positions.

Action: Open the attribute table of the shpfile 'RillPoints_Elev_Max' Action: Add a numeric field (as double) named 'Difference'

Action: Perform 'Field Calculator' over the 'Difference' field: [RASTERVALUE] - [grid_code]

Result: Rill depth (map units) for each rill point

\section{STEP 11: Joining}

Since Steps 8, 9 and 10 are repeated many times as the number of radius chosen, at the end of analyses the results must be joined in a unique shpfile.

Action: Open the Attribute Table of the shpfile 'RillPoints_Elev_Max' Action: Right click on Table Options

Action: Joins and Relates > Join

Join Data dialog box - Choose the field in this Layer(...): Pointid

Join Data dialog box - Choose the table to join: (Tables in turn from

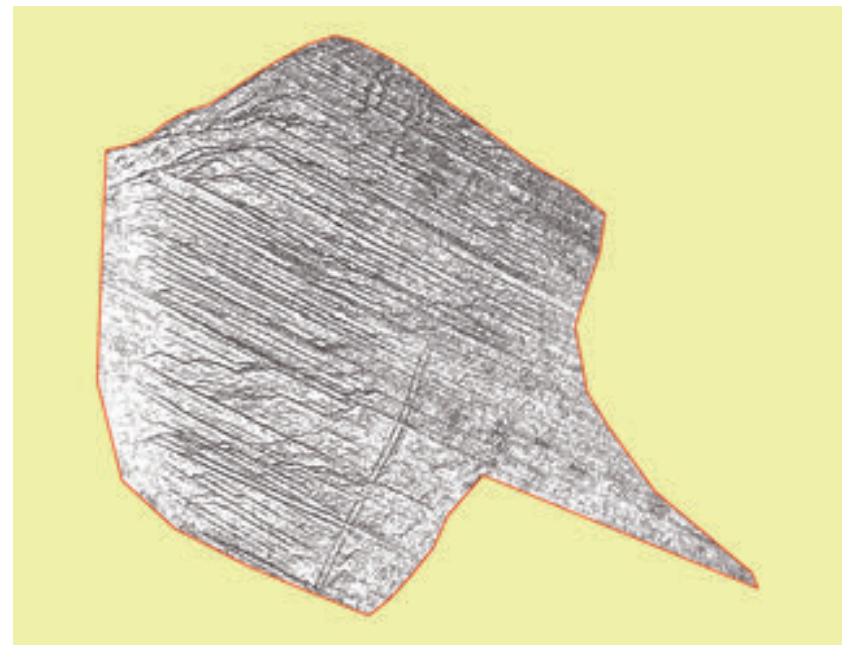

Figure 14. Value 1 is assigned to rill cells (black), 'Null' (no data) is assigned to no-rill cell (white).

Table
Rill_Elev_Points
\begin{tabular}{|r|r|r|r|}
\hline OBJECTID * & Shape * & pointid & grid_code \\
\hline 1 & Point & 1 & 92.34045 \\
\hline 2 & Point & 2 & 92.35432 \\
\hline 3 & Point & 3 & 92.30703 \\
\hline 4 & Point & 4 & 92.31119 \\
\hline 5 & Point & 5 & 92.31776 \\
\hline 6 & Point & 6 & 92.32455 \\
\hline 7 & Point & 7 & 92.33774 \\
\hline 8 & Point & 8 & 92.29089 \\
\hline 0 & Doint & 0 & 020122 \\
\hline
\end{tabular}

Figure 15. Resulting table from raster to point transformation. The elevation of each rill cell is reported in the field named gridcode.

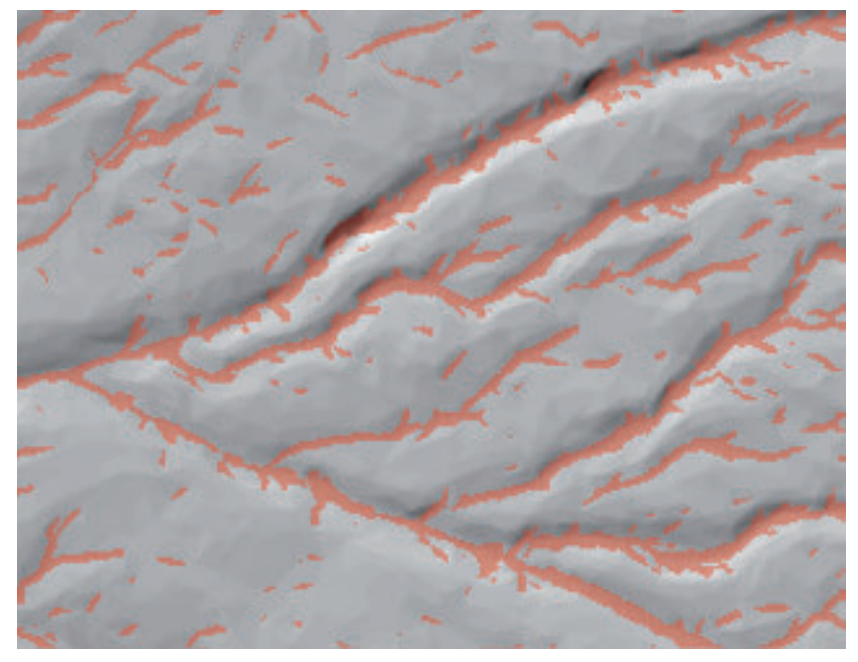

Figure 16. Representation of rill cells converted into points (in red). 
STEP10)

Join Data dialog box - Choose the field in the table to base the join on: Pointid

Join Options: Keep all records

Action: Save all the joins in a new shpfile 'Joined_Radii_Depths'

STEP 12: Adding curvature value to points

The curvature value determined in STEP 3 must be added to each rill point. This value is necessary to perform a successive selection of points based on this attribute.

ArcToolbox: Spatial Analyst Tools > Extraction > Extract Values to Points

Input Point Features: 'Joined_Radii_Depths'

Input raster: PICu_Plot (see STEP 3)

Output point features: 'Joined_Radii_Depths_PICu'

Interpolate values at the point locations: box not flagged

Append all the input raster attributes to the output point features: box flagged. At the end of STEPS 11 and 12 the resulting Attribute Table of the shpfile 'Joined_Radii_Depths_PICu' will appear as represented in Figure 18.

STEP 13: Selection of rill point depths according to plan curvature values and radius of neighbouring circle

As already reported in the chapter on Focal Statistics, rill points must be separated into groups according to different ranges of Plan curvatures values. For each group the user must calculate the statistics on depths as calculated by FocalDiff analysis by using the proper radius.

The choice of ranges of Plan curvature was done by overlapping the point shpfile 'Joined_Radii_Depths_PICu' on the orthophoto and by selecting, in the layer properties, the PlanCurv field as graduated color (with very large dataset it would be necessary to increase the Sample Size in the 'Data Sampling' windows under 'Classification'). In Figure 19 the result of this operation is shown.

In this exercise, 3 groups were considered:

1) plan curvature values spanning -60 -26.436832. For these points, we decided to consider the depths calculated by the $15 \mathrm{~cm}$ radius as the most appropriate. In fact the rim is very close to these rill points (yellow group).

2) plan curvature values spanning -610 -125. For these points, placed in the deepest position of large rills, we decided to consider the depths calculated by the $30 \mathrm{~cm}$ radius as these points are the most distant from the rill rims (magenta group).

3) plan curvature values spanning $-125-60$, includes rill points in between the two previous categories, so that we decided to consider the depths calculated by the $25 \mathrm{~cm}$ radius (cyan group).

The selection of points according to Plan Curvature ranges was done as follows:

Each group of rill points belonging to the ranges of Plan curvature values must be selected in turn from the Table, by using the following commands:

Open attribute Table of the shpfile 'Joined_Radii_Depths_PlCu' > Click Selection > Select By Attributes

Method: Create a new selection

Type the desired SQL query into the selection windows, for three times in turn according to the 3 different range values,.

In this exercise:

SQL query to select points for which $15 \mathrm{~cm}$ is the proper radius size:

'PlanCurv ' <= -26.436832 AND ' PlanCurv ' >-60

SQL query to select points for which $25 \mathrm{~cm}$ is the proper radius size:

'PlanCurv' > -125 AND ' PlanCurv ' $<=-60$

SQL query to select points for which $30 \mathrm{~cm}$ is the proper radius size:

'PlanCurv ' > = -609.033447 AND ' PlanCurv '<=-125
STEP 14: Statistics of depth values of rill points selected by ranges of Plan curvature values

After each selection performed by the SQL query, statistical parameters of selected points must be calculated on the proper depth field of the attribute table of the shpfile 'Joined_Radii_Depths_PICu'.

\begin{tabular}{|c|c|c|c|c|c|c|}
\hline \multicolumn{7}{|c|}{ Table } \\
\hline \multicolumn{7}{|c|}{ RillPoints_Elev_Max } \\
\hline & OBNECTID : & Shape" & pointid " & grid_code & RASTERVALU & Difference \\
\hline & 1 & Point & 1 & 92.34045 & 92.399933 & 0.059486 \\
\hline & 2 & Point & 2 & 92.35432 & 92.414139 & 0.059814 \\
\hline & 3 & Point & 3 & 92.30703 & 92.377747 & 0.070717 \\
\hline & 4 & Point & 4 & 92.31119 & 92385353 & 0.074165 \\
\hline & 5 & Point & 5 & 92.31776 & 92392609 & 0.074552 \\
\hline & 6 & Point & 6 & 92.32455 & 92.399933 & 0.075376 \\
\hline & 7 & Point & 7 & 82.39774 & 92.414139 & 0.078401 \\
\hline & 8 & Point & 8 & 92.29089 & 92.33503 & 0.044144 \\
\hline & 9 & Point & 9 & 92.29168 & 92.346907 & 0.057228 \\
\hline & 10 & Point & 10 & 92.28529 & 92.362785 & 0.067497 \\
\hline & 11 & Point & 11 & 92.29945 & 92.374542 & 0.075096 \\
\hline & 12 & Point & 12 & 92.3038 & 92.381798 & 0.078194 \\
\hline & 13 & Point & 13 & 92.3092 & 92.389053 & 0.079849 \\
\hline
\end{tabular}

Figure 17. Attribute Table of the shpfile 'RillPoints_Elev_Max'. DEM elevations are reported in the field 'grid code'. The field 'Difference' reports, for each rill point, the difference between rim elevation (RASTERVASLUE field) and point elevation ('grid_code' field).

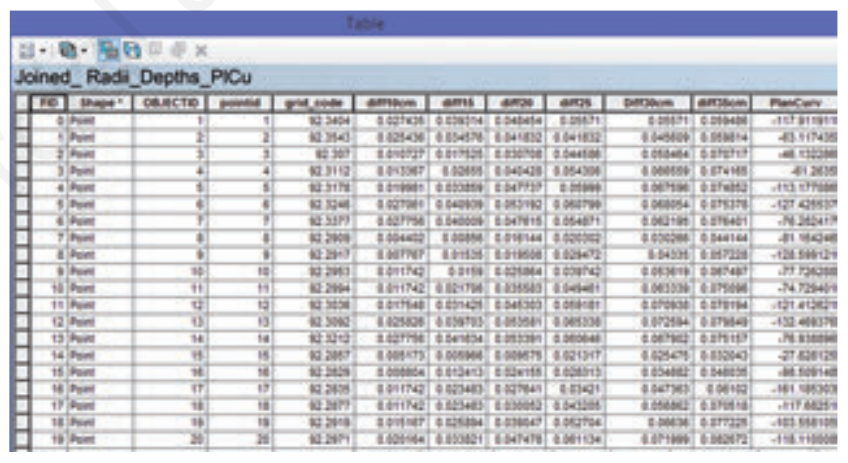

Figure 18. The result shpfile 'Joined_Radii_Depths_PICu'

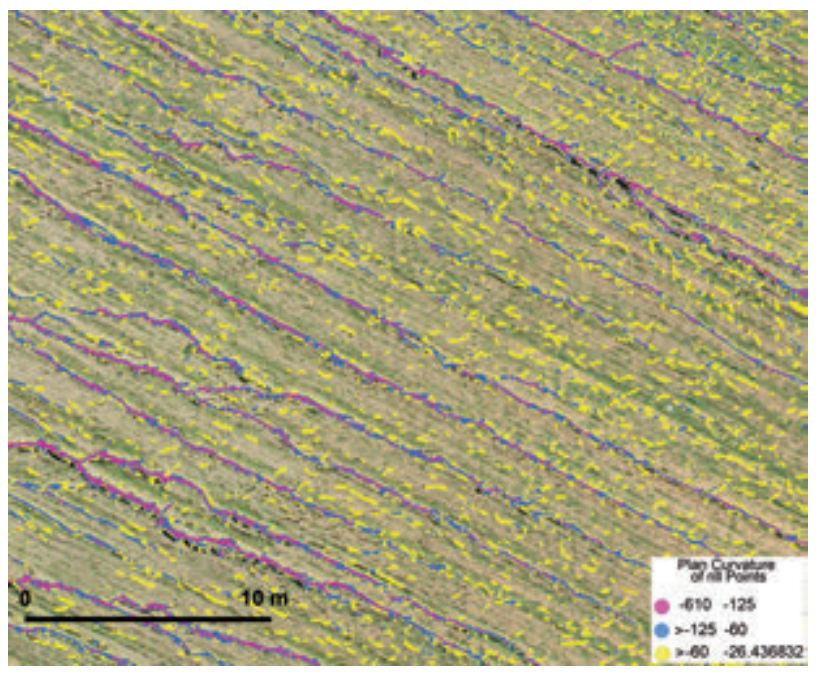

Figure 19. Rill points grouped by plan curvature values. 
Example for selected points for which $15 \mathrm{~cm}$ is the proper radius size: After point selection: Right-click on the field 'diff15' of the Attribute Table, then click on Statistics. The statistical parameters 'Count' and 'Mean' of each group of points are used to calculate rill erosion in the following step.

\section{STEP 15: Rill erosion calculation}

To calculate total rill erosion (Table 6) it is necessary to know the bulk density of soil at UAV-survey time and the plot area.

In this example exercise the average bulk density, detected through core method on field, resulted in $1.247 \mathrm{t} / \mathrm{m}^{3}$. The plot area is $1.5776 \mathrm{ha}$.

For each group of points the total area of DEM cells belonging to rills is calculated by multiplying the counts (obtained from statistics) by the pixel area.

The volume of excavation for each selected group of points is calculated by multiplying the area by the mean depth of rill points.

Calculation for each group of rill points selected by ranges of Plan curvature values:

Rill Area: Count (n. of rill points) $* 0.0479^{2}($ pixel area $)=$ area $\mathrm{m}^{2}$

Rill Volume: area $\mathrm{m}^{2 *}$ mean depth $(\mathrm{m})=$ volume $\mathrm{m}^{3}$

Rill erosion: total of rill volume by groups $\left(\mathrm{m}^{3}\right){ }^{*}$ bulk density (1.247 $\left.\mathrm{t} / \mathrm{m}^{3}\right)=$ tonnes

Specific Rill erosion: tonnes / ha $(1.5776)=$ t/ha

\section{EXERCISE N.2 (Fagna, Florence)}

Lightly eroded field. Two diachronic DEMs analysed.

\section{Site description}

WGS84 Coordinates of plot centroid: N $43^{\circ} 59^{\prime} 01.29^{\prime}$; E $11^{\circ} 21^{\prime}$ 06.57' (Mugello valley).

Type: field plot

Area: 1.1783 ha

Mean Slope: $14.4 \%$

Maximum length along the slope gradient: $250.7 \mathrm{~m}$

Geology: Pedogenized Pleistocene lacustrine deposits.

Soil classification: Typic Udorthents (Soil Survey Staff, 2014), silty clay texture (USDA, 2015).

Grain size distribution: Total Sand $17.5 \%$, Total Silt $42.0 \%$, Clay

40.5\%, 0.M. $1.67 \%$.

Bulk density at UAV survey time: $1.222 \mathrm{t} / \mathrm{m}^{3}$

\section{UAV-Survey conditions and DEM resolution}

Mean flying altitude (m): 49.97

GCP spacing: on a square grid $40 \times 40 \mathrm{~m}$
Photomosaic resolution (m/pix): 0.01132

DEM resolution (m/pix): 0.0572

UAV survey flight $n .1$ on $25 / 12 / 2013$. DEM name: DEM $_{\text {dec13 }}$

UAV survey flight $n .2$ on 26/01/2014. DEM name: DEM $_{\text {jan14 }}$

In Figure 20 the orthomosaic of the study plot at second flight time is reported.

In Figure 21 a close up view of a downhill portion of the plot at first flight date before soil erosion had occurred is shown. It is possible recognize the false rill incisions determined by cultivation tools. In Figure 22 the same piece of plot of Figure 21 after rilling is shown. False rills are still present on the soil surface (Figure 23) and this justify the need of the diachronic analysis of the two DEMs (before and after erosion has occurred).

\section{STEPS 1 to 7}

Idem as in exercise n.1. Performed on both $\mathrm{DEM}_{\mathrm{dec} 13}$ and $\mathrm{DEM}_{\mathrm{jan14}}$

STEP 7.1.: Selecting false rill points from the before-erosion DEM

It must be considered that not all rill cells detected on the $\mathrm{DEM}_{\text {dec13 }}$ are also present on the $\mathrm{DEM}_{\mathrm{jan} 14}$. Consequently, the analysis of false rill depth for $\mathrm{DEM}_{\text {dec13 }}$ must be performed only for points which are also present in 2014.

The shpfile of rill points of January 2014 is used to extract the DEM values of rill cells of December 2013.

The raster of Rill cells of December 2013 (Rill_elev_dec13) is

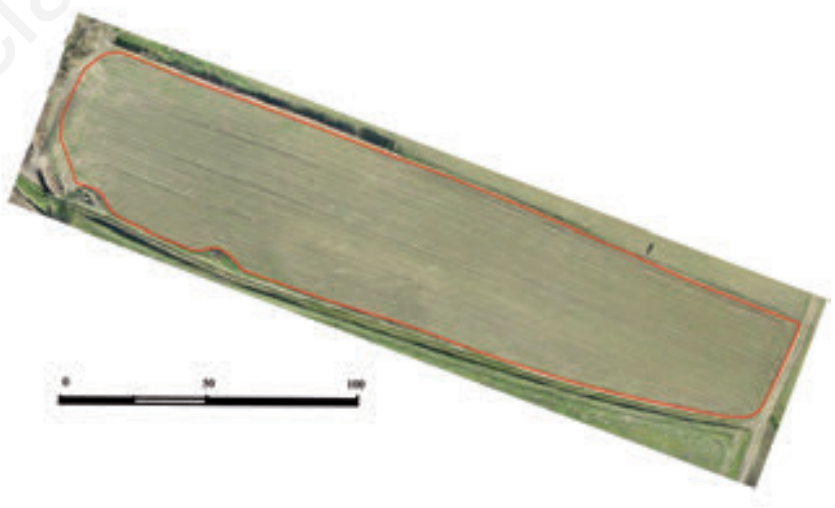

Figure 20. The 1.18 ha plot of the example exercise n. 2 .

Table 6. Statistics of depth values for groups of rill points selected by ranges of Plan curvature values and Rill erosion results.

\begin{tabular}{|c|c|c|c|}
\hline & Radius 15 & $\begin{array}{l}\text { by ranges of Plan curvature values } \\
\text { Radius } 25 \mathrm{~cm}\end{array}$ & Radius $30 \mathrm{~cm}$ \\
\hline $\begin{array}{l}\text { From statistics } \\
\text { Count (n. of rill points) } \\
\text { Mean depth of rills (m) } \\
\text { Maximum depth of rills (m) } \\
\text { Minimum depth of rills (m) }\end{array}$ & $\begin{array}{c}660,994 \\
0.02377 \\
0.129295 \\
0\end{array}$ & $\begin{array}{l}346,468 \\
0.048325 \\
0.225693 \\
0.002625\end{array}$ & $\begin{array}{c}97,265 \\
0.031905 \\
0.24098 \\
0.001457\end{array}$ \\
\hline $\begin{array}{l}\text { Calculations } \\
\text { Area of rill cells }\left(\mathrm{m}^{2}\right) \\
\text { Volume of rills }\left(\mathrm{m}^{3}\right)\end{array}$ & $\begin{array}{c}1516.59 \\
36.05\end{array}$ & $\begin{array}{c}794.94 \\
38.42\end{array}$ & $\begin{array}{c}223.17 \\
7.12\end{array}$ \\
\hline $\begin{array}{l}\text { Total volume }\left(\mathrm{m}^{3}\right) \\
\text { Total rill erosion }(\mathrm{t}) \\
\text { Rill erosion by ha }(\mathrm{t} / \mathrm{ha})\end{array}$ & & $\begin{array}{c}81.59 \\
101.74 \\
64.49\end{array}$ & \\
\hline
\end{tabular}


obtained by following the above STEP 6 .

In the point shpfile resulting from extraction, records with -9999 value in the field 'RASTERVALUE' of elevations December 2013 must be removed. In fact, they correspond to rill points of Jan. 2014 which were not present in December 2013 (Figure 24).

ArcToolbox: Spatial Analyst Tools > Extraction > Extract Values to Points

Input Point Features: Rill_Elev_Points_jan14

Input raster: Rill_elev_dec13

Output point features: RillPoints_match_dec13jan14

Interpolate values at the point locations: box not flagged

Append all the input raster attributes to the output point features: box flagged

Open the attribute table of the shpfile RillPoints_match_dec13jan14: select and delete records with -9999 value in the field 'RASTERVALUE' of elevations December 2013.

\section{STEPS 8 to 15}

Idem as in exercise n.1. Performed on both $\mathrm{DEM}_{\mathrm{dec} 13}$ and $\mathrm{DEM}_{\mathrm{jan} 14}$

The only difference was the use of one radius length only of $10 \mathrm{~cm}$ for both DEMs because it was sufficient according to the rill width (much smaller than in the plot at Tor Mancina, exercise 1).

\section{STEP 11: Rill erosion calculation}

Subtraction: Rill volumes as detected for $\mathrm{DEM}_{\mathrm{jan} 14}$ minus false rill volume as detected for $\mathrm{DEM}_{\text {dec13 }}$ as shown in Table 7.

Done: Soil bulk density $1.222 \mathrm{t} / \mathrm{m}^{3}$; plot area 1.178ha; DEM's cell size $0.05 \mathrm{~m}$.

\section{Interrill erosion evaluation}

The proposed UAV-GIS methodology does not enable the measurement of interrill erosion because this process does not determine interrill surfaces affected by curvature.

For the purpose of this paper the evaluation of the interrill portion of soil erosion is made from the measured value of rill erosion by calculating the ratio of rill to interrill erosion $(\beta)$, according to McCool et al. (1989) who proposed the equation for soils susceptible to rilling.

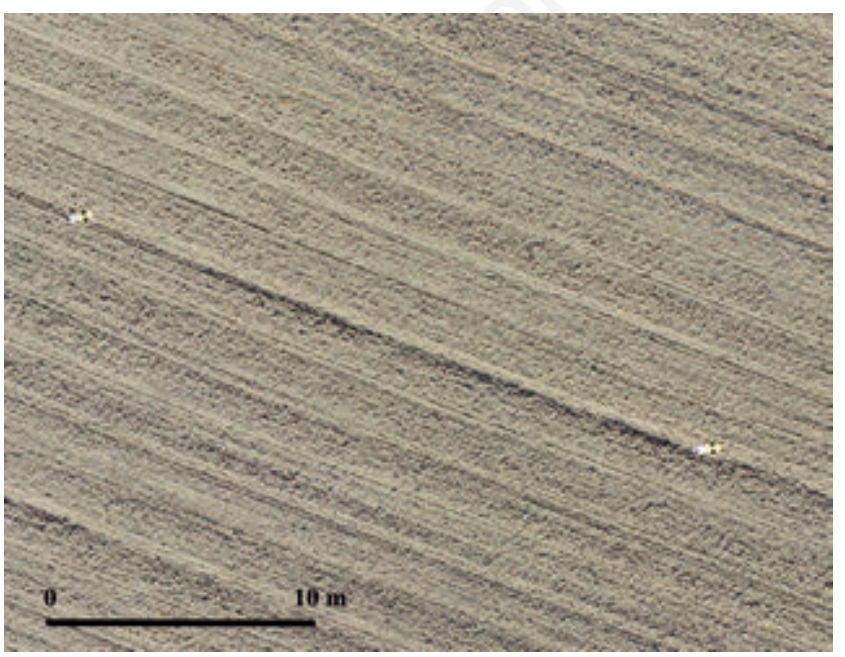

Figure 21. Close up view of a downhill portion of the same plot of Figure 19 at first flight time, before soil erosion has occurred.

$$
\beta=\frac{11.16 \sin \theta}{0.56+3(\sin \theta)^{0.8}}
$$

where is the slope angle ( sexagesimal degrees). For soils that have low or high susceptibility to rilling $\beta$ is respectively halved or doubled. Therefore, to determine the value of beta it is necessary to evaluate the susceptibility to rilling. Susceptibility to rilling depends on a number of factors such as the slope steepness, soil characteristics, management, stoniness etc. In order to simplify, we assumed that susceptibility to rilling can be effectively described by the factor K erodibility factor of RUSLE (Renard et al., 1997) or, more easily, by K of USLE (Wischmeier e Smith; 1978) calculated through the equation (5), (valid for soils containing less than 70 percent silt and very fine sand).

$$
\mathrm{K}_{\text {(USLE) }}=\left[\left(2.1 \mathrm{M}^{1,14}\left(10^{-4}\right)(12-\mathrm{a})+3.25(\mathrm{~b}-2)+2.5(\mathrm{c}-3)\right] / 100\right.
$$

where K (U.S. customary units); (M) is the percent silt (0.1-0.002 mm) times the quantity 100 minus percent clay; (a) percent organic matter, (b) is the soil-structure code used in soil classification (1= very fine granular $<1 \mathrm{~mm}$; 2 fine granular $1-2 \mathrm{~mm} ; 3=$ =medium or coarse granular 2-10 mm; $4=$ blocky, platy, massive) and c is the permeability class ( $1=$ rapid $>130 \mathrm{~mm} \cdot \mathrm{h}^{-1} ; 2=$ moderate to rapid $60-130 \mathrm{~mm} \cdot \mathrm{h}^{-1} ; 3=\bmod$ erate $20-60 \mathrm{~mm} \cdot \mathrm{h}^{-1} ; 4=$ moderate to slow $5-20 \mathrm{~mm} \cdot \mathrm{h}^{-1} ; 5=$ slow $1-5$ $\mathrm{mm} \cdot \mathrm{h}^{-1} ; 6=$ very slow $\left.<1 \mathrm{~mm} \cdot \mathrm{h}^{-1}\right)$. When the value of permeability is unknown it is recommended to use the class 4 .

The Soil Erosion Risk Assessment in Europe (Van der Knijff et al., 2000) highlighted that erodibility of volcanic soils is very high and it depends more on physical and chemical properties rather than texture. For these soils the erodibility cannot be predicted by Equation (4) and a value of 0.607 (US customary units) was assigned to all volcanic soils. The calculated $\mathrm{K}$ factor is used to evaluate the class of susceptibility to rilling from Table 8 and to decide whether to keep the same, halve or double the ratio of rill to interrill erosion $(\beta)$. This decision cannot ignore the visual evaluation of the soil surface. For example, if the susceptibility to rilling resulted in the class 'high' but rills are scarce due to rainfall scarcity, it is preferable not to change or even decrease the value of $\beta$.

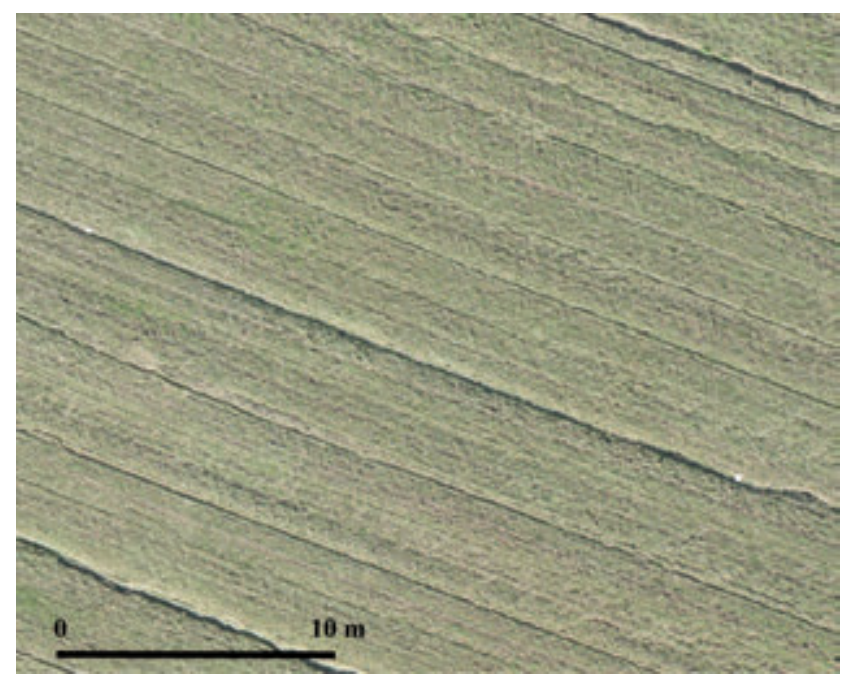

Figure 22. Close up view of the same portion of the same plot of Figure 19 at the second flight time (after erosion had occurred, one month after the previous UAV survey. 


\section{Exercise 3: Interrill erosion calculation for plots of exercises 1 and 2}

Question

Evaluate interrill erosion occurred in the study Plots at Tor Mancina and Fagna from soil particle size distribution, slope gradient $\%$, by calculating the ratio of rill to interrill erosion $(\beta)$.

Tor Mancina data

Total Rill erosion as determined by UAV-GIS methodology in exercise n.1 $=64.49$ t/ha

Slope gradient $\%=15.4$

total clay $\%=30.7$ fine sand $\%=35.3$

total silt $\%=30.0$

$0 \mathrm{M} \%=1.61$

structure code $(\mathrm{SC})=3$

permeability class $(\mathrm{PC})=5$

$\mathrm{M}=(\%$ silt+\%fine sand $)(100-\%$ clay $)=4525.3$

Fagna data

Total Rill erosion as determined by UAV-GIS methodology in exercise n. $2=16.08 \mathrm{t} / \mathrm{ha}$

Slope gradient $\%=14.4$

total clay $\%=40.5$

Table 7. Statistics of depth values for DEMdec13 and DEMjan14 and rill erosion results by difference.

\begin{tabular}{|c|c|c|c|}
\hline & DEM $_{\text {dec13 }}$ false rills & DEM rills & Rills volumeminus false rills volume \\
\hline \multicolumn{4}{|l|}{ From statistics: } \\
\hline Count (n. of rill points) & 303,572 & 755,535 & \\
\hline Mean depth of rills (m) & 0.013757 & 0.013817 & \\
\hline Maximum depth of rills (m) & 0.06604 & 0.06781 & \\
\hline Minimum depth of rills (m) & 0.000595 & 0.000458 & \\
\hline \multicolumn{4}{|l|}{ Calculations: } \\
\hline Area of rill cells $\left(\mathrm{m}^{2}\right)\left(0.0025 \mathrm{~m}^{2}\right.$ each $)$ & 758.93 & 1888.84 & \\
\hline Volume of rills $\left(\mathrm{m}^{3}\right)$ & 10.44 & 25.95 & 15.51 \\
\hline Total Rill erosion (t) & & & 18.95 \\
\hline Rill erosion by ha (t/ha) & & & 16.08 \\
\hline
\end{tabular}

Table 8. Susceptibility of soil to rilling as determined though the classes of $\mathrm{K}$ (soil erodibility). (classes of $\mathrm{K}$ available at: http://www.iwr.msu.edu/rusle/kfactor.htm).

\begin{tabular}{ccc} 
K erodibility classes and susceptibility to rilling & $\begin{array}{c}\text { K (US units) } \\
\text { (tons.acre.hr)/(hundreds.acre.ft.tonsf.in) }\end{array}$ \\
Low & $0.05<0.25$ \\
Moderate & $0.25-0.4$ \\
\hline High & $>0.4$ \\
\hline
\end{tabular}

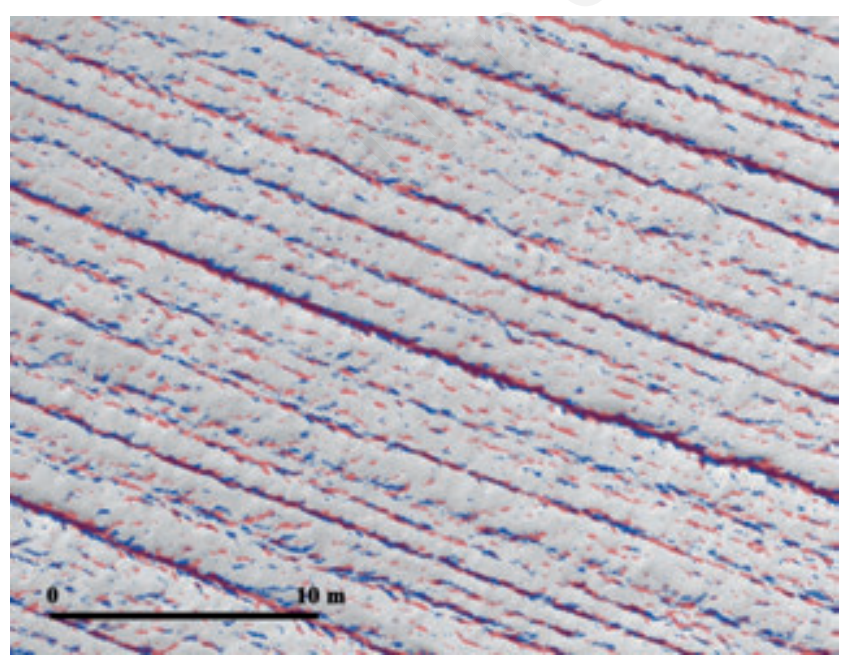

Figure 23. Close up view of the shadowed portion of the same plot of Figure 19. In blue and red false and true rills have been respectively found through planar curvature analysis. Transparency was applied to true rills (red) to evidence the coincidence of position with false rills (blue) in many locations.

\begin{tabular}{|c|c|c|c|c|c|}
\hline & & & Tat & & \\
\hline & 18. 是 & $8 \square$ & $\mathrm{x}$ & & $\begin{array}{l}\text { Elevations } \\
\text { ise rili points }\end{array}$ \\
\hline & Points_matc & h_dec13 & & & y \\
\hline & OBNECTID * & Shape * & pointi & grid_code & RASTERVALU \\
\hline • & 1 & Point & & 245.0501 & 245.060638 \\
\hline & 2 & Point & & 245.0464 & $\begin{array}{r}-9999 \\
\end{array}$ \\
\hline & 3 & Point & & 245.0521 & -9999 \\
\hline & 4 & Point & & 245.0536 & -9999 \\
\hline & 5 & Point & & 245.0678 & 245.089752 \\
\hline & 6 & Point & & 245.0445 & -9999 \\
\hline & 7 & Point & & 245.0539 & .9999 \\
\hline & 8 & Point & & 245.055 & .9999 \\
\hline & 9 & Point & & 245.0569 & .9999 \\
\hline & 10 & Point & & 245.0596 & -9999 \\
\hline & 11 & Point & & 245.0622 & -9999 \\
\hline
\end{tabular}

Figure 24. Matching table of elevation of rill points. December 2013 (before erosion) and January 2014 (after erosion). 
fine sand $\%=15.1$

total silt $\%=42.0$

$0 \mathrm{M} \%=1.67$

structure code $(\mathrm{SC})=3$

permeability class $(\mathrm{PC})=3$

$\mathrm{M}=(\%$ silt+\%fine sand $)(100-\%$ clay $)=3397.45$

\section{Solved (Tor Mancina plot) exercise}

$\mathrm{K}_{\text {(USLE) }}$ according to Wischmeyer and Smith, 1978

(Microsoft Excel formula):

$=\left(\left(2.1^{*} \mathrm{M}^{\wedge} 1.14\right) *\left(10^{\wedge}-4\right) *(12-0 \mathrm{M} \%)+3.25^{*}(\mathrm{SC}-2)+2.5^{*}(\mathrm{PC}-\right.$

3)) $/ 100$

Result: $\mathrm{K}=0.403(\mathrm{~K}=0.607$ was adopted instead of the calculated value, according to Van der Knijff et al., 2000 for volcanic soil of Italy)

Result: Susceptibility to rilling (from table) $=$ High

$\beta$ (Microsoft Excel formula $)^{4}$

$=(11.16 * \operatorname{ASIN}(\operatorname{RADIANS}((\operatorname{ATAN}($ slope $\% / 100)) * 180 / \mathrm{PI}(0))) /((($ ASI

$\left.\left.\left.\mathrm{N}(\operatorname{RADIANS}((\operatorname{ATAN}(\text { slope } \% / 100)) * 180 / \mathrm{PI}(0)))^{\wedge} 0.8\right) * 3\right)+0.56\right)$

Provisional Result: $\beta=1.392$

Result: $\beta_{\text {adjusted }}=1.392 * 2=2.785$

Interrill erosion $=$ Rill erosion $/ 2.785$

Result interrill erosion $=64.49 / 2.785=23.15$ t/ha

Total soil erosion $64.49+23.15=87,64$ t/ha

\section{Solved (Fagna plot) exercise}

Result: $\mathrm{K}_{(\mathrm{USLE})}=0.037$

Result: Susceptibility to rilling (from table) $=$ Moderate

Provisional Result: $\beta=1.340$ (no adjustment is needed)

Interrill erosion $=$ Rill erosion $/ 1.340$

Result interrill erosion $=16.08 / 1.340=12.0$ t/ha

Total soil erosion $16.08+12.0=29.08$ t/ha

\section{Comparison between UAV-GIS and RUSLE-GIS erosion}

Specific soil erosion (t/ha) rates for the Tor Mancina and Fagna plots, as determined by applying the UAV-GIS methodology and the calculus of interrill erosion according to McCool et al. (1989), were compared to the estimated values by applying the RUSLE model in GIS environment. This exercise has been done in order to have a confirmation of the validity of the new UAV-GIS methodology and consequently to have an idea if the methodology can be used to calibrate RUSLE for the uses of CAP.

As known, DEM resolution influences greatly the $\mathrm{L}$ and $\mathrm{S}$ factor of RUSLE with consequent variation of the sediment transport ratio. $\mathrm{L}$ factor varies on the grid size and the steepness while $\mathrm{S}$ factor is influenced only by steepness. Oliveira et $a$ l. (2013) report that the best sediment production estimates were observed when DEM cell resolution approaches $22.4 \mathrm{~m}$, which is the length of standard plots used in the derivation of the USLE model. For this reason, in this comparison exercise, $20 \times 20 \mathrm{~m}$ DEMs were used instead of the original high resolution DEMs. 20-m DEMs were produced by resampling the original DEMs. Another reason for using 20-m DEMs is that Italian Regions generally adopt, for soil erosion estimates, the official $20 \mathrm{~m}$ resolution Digital

${ }^{4} \beta$ (Microsoft Excel function in Italian): $=(11.16 * \operatorname{ARCSEN}(\operatorname{RADIANTI}((\operatorname{ARCTAN}($ slope $\% 100)) * 180 / \mathrm{PI}$. GRECO $(0))) /\left(\left(\left(\left(\operatorname{ARCSEN}(\operatorname{RADIANTI}((\operatorname{ARCTAN}(\text { slope\%/100) }) * 180 / \text { PI.GRECO }())))^{\wedge} 0.8\right) * 3\right)+0.56\right)\right.$
Elevation Model provided for by the Italian Ministry of Environment (MATTM).

From Table 9 it is possible to argue that, for Tor Mancina plot, results of RUSLE model and UAV-GIS methodology are quite well in accord. For the Fagna plot, the results differ greatly from one another, even if it both methods highlight the presence of heavy erosion. From soil erosion of 9 plots surveyed through the MO.NA.CO. project (Bazzoffi et al., 2015) it was possible to compare soil erosion estimated by RUSLE with the UAV-GIS measurements.

Mean separation via the Duncan test (Table 10) shows that there is no significant difference between the observed and predicted values with the RUSLE model. Table 11 shows the regression summary. Despite the few observations at our disposal the agreement between RUSLE estimated erosion and the observed soil erosion through the UAV-GIS methodology resulted quite satisfactory.

\section{Discussion and conclusions}

Soil erosion measurement through the UAV-GIS methodology integrated by the calculus of interrill erosion appears suitable for the purpose of evaluating the effectiveness of some soil conservation actions adopted under CAP and a valid cost-effective compromise respect to existing methods for measuring soil erosion on field through runoff plots. In general, from calibration results it can be said that the UAVGIS methodology can be used to detect rill depth, taking care to use the appropriate radius length in the Focal statistics analysis. Moreover, the acceptable comparison between observed erosion rates obtained through the new methodology and RUSLE lead us to believe that the new methodology can be applied. Nevertheless, there are some limitations, some of them due to the UAV photogrammetry and other limitations linked to some choices left to the user when using GIS, that are able to greatly change the results.

It is important to remember that there is no methodology to measure erosion which can be considered as an absolute reference against which all other methods have to compare. Even the method of measuring with the runoff plots is not free from severe criticism (Hudson, 1993; Stroosnijder, 2005). For this reason it is difficult to find a term of comparison to test the new methodology. Both of the above-mentioned kinds of limitations of UAV-GIS methodology can be partly, but not totally, overcome by: i) refinement of UAV survey through the improvement of the camera or by using different sensor carried by drone; ii) correct choice of sky conditions for the execution of the flight, by giving preference to scattered light conditions; and iii) direct observation of the soil surface before and after erosion has occurred in order to solve some doubts that can arise when observing the orthophoto. Also an increasing experience in UAV photo interpretation and repeated application of the UAV-GIS methodology by different GIS expert can help achieve of better results.

In our experience the morphological definition of a rill is not a simple task. Also when working manually on the field, it is sometimes difficult to measure rill width. The edges of a rill can be very irregular, or instead of having a U-shaped or V-shaped form they may have a modest slope (especially the downstream rim), so it is difficult to define exactly the limit between rill and interrill areas. In addition, when rill is large without any parallel rims it is impossible, even by hand, to define the cross section along which to measure rill depths. The new methodology simplifies these problems by finding, for each rill point, the difference between the elevation of the rill rim and the point elevation.

The Plan curvature threshold and the length of the radius of neighbouring circle are crucial choices that can lead to very different results. We found that the plan curvature threshold value, to delineate rills, is not very difficult to decide. A good choice can be easily reached by 
Table 9. Comparison between estimated (RUSLE model) and measured soil erosion (UAV-GIS).

\begin{tabular}{lccccccc} 
Site & \multicolumn{4}{c}{ RUSLE factors } & \multicolumn{2}{c}{$\begin{array}{c}\text { RUSLE_GIS } \\
\text { erosion (t/ha) }\end{array}$} & $\begin{array}{c}\text { UAV-GIS measured plus interrill } \\
\text { erosion estimated (t/ha) }\end{array}$ \\
Fagna & 1550.14 & 0.040 & 29.08 & 1.00 & 1.00 & 66.39 & 29.08 \\
Tor Mancina & 6580.82 & 0.054 & 87.64 & 1.00 & 1.00 & 79.38 & 87.64 \\
\hline
\end{tabular}

LS, topographic factor calculated according to Nearing ( 1997).

Table 10. Duncan test for mean separation (observed erosion and RUSLE-predicted erosion) and Levene's test for homogeneity of variances.

\begin{tabular}{|c|c|c|c|}
\hline 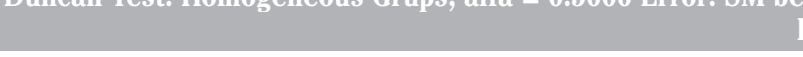 & an $\left(t \mathrm{ha}^{-1}\right.$ period $\left.^{-1}\right)$ & \multicolumn{2}{|c|}{1} \\
\hline Observed erosion & 27.34 & \multicolumn{2}{|c|}{$* * * *$} \\
\hline RUSLE erosion & 36.83 & \multicolumn{2}{|c|}{$* * * *$} \\
\hline $\begin{array}{r}\text { Levene's test of variance homogeneity F.D. for all F: } 1,16 \\
\text { MS Effect }\end{array}$ & MS Error & F & p \\
\hline Erosion & 191.72 & 1.42 & 0.250 \\
\hline
\end{tabular}

Table 11. Summary of regression between RUSLE-predicted erosion and the measured values with the UAV-GIS methodology.

\begin{tabular}{|c|c|c|c|c|c|c|}
\hline \multicolumn{7}{|c|}{ Regression $\quad R^{2}=0.797 \mathrm{~F}(1,7)=27.467 \mathrm{P}<0.0120$ St. Err. Est.: 13.58} \\
\hline & Beta & Std. Err.of Beta & B & Std. Err. of B & $t(7)$ & P-level \\
\hline Intercept & & & -1.843 & 7.178 & -0.257 & 0.805 \\
\hline RUSLE erosion & 0.893 & 0.170 & 0.793 & 0.152 & 5.240 & $0.001^{* *}$ \\
\hline
\end{tabular}

observing graduated colours for different range quantities of curvature values overlapped to the orthomosaic and to the hillshade of DEM (different hillshade layers, produced by changing illumination parameters, can greatly help when choosing). For both of the analysed plots the plan curvature value of -26.4368 was effective in detecting the rills. Thus, we suggest to consider this value for DEM of about $5 \mathrm{~cm}$ cell size. The radius length is the most crucial parameter especially for plots where rill width varies very much from large to small. Because radius length must be as small as possible to intercept the rill rim, it may be needed to differentiate the length according to point position inside the rill. Point position inside a rill can be defined by the associated value of plan curvature. Another strategy can be that of dividing the plot into sub-zones of prevailing rill widths and to perform separate analyses by applying different radius lengths of neighbouring circles. Anyway the user can identify the most appropriate approach of analysis, also composite, according to the specific situation of the field studied.

The other problem that arises on feebly eroded agricultural soil is to remove from the volume calculation of rill the part of volume determined by mechanical incision due to cultivation tools and machinery that passes on the soil (false rills). When soil erosion is feeble, scouring water deepens the existing mechanical incisions and rills erosion cannot be attributed to the total volume of incision detected after erosion has occurred.

The second solved exercise is about a rilled plot in which the diachronic analysis of DEMs was considered necessary to remove the volume of false rills (mechanical incisions) which were still present on the soil surface after soil erosion has occurred. As already mentioned in the preface it would seem intuitive to measure rills volume by a simple diachronic comparison of two DEM's representing the same surface respectively before and after soil erosion has occurred, on the assumption that the elevation of the soil surface would change only due to soil erosion. This assumption however is not always true and cannot be easily verified because DEM modification can be determined also by post-tillage consolidation of soil, by mass movements, by soil deformation due to shrink-swell of clay minerals in relation to soil moisture changes (Bronswijk, 1991; Brake et al., 2103).

The solution adopted in exercise 2 to remove the false-rill effect is also a compromise which may not be free from criticism. The weakest aspect is the subjective judgement if mechanical incisions still play a relevant role in determining the volume of rills after erosion has occurred. This problem can be partly solved by direct observation of the morphology of rills on the field. In the Fagna plot of exercise 2 this kind of judgement was of crucial importance. In fact, the orthophoto of the field after erosion, previously reported in the text, is able to show the evident presence of residual mechanical incisions only to some extent. The estimation of interrill erosion according to McCool et al. (1989) has been reported in the text but no further validation has been made.

\section{References}

Bazzoffi P, Francaviglia R, Neri U, Napoli R, Marchetti A, Falcucci M, Pennelli B, Simonetti G, Barchetti A, Migliore M, Fedrizzi M, Guerrieri M, Pagano M, Puri D, Sperandio G, Ventrella D, 2015. Environmental effectiveness of GAEC cross-compliance standard 1.1a 'temporary ditches' and $1.2 \mathrm{~g}$ (permanent grass cover of setaside) in reducing soil erosion and economic evaluation of the competitiveness gap for farmers. Ital. J. Agron. 10(s1):710.

Brake B, Hanssen RF, Van der Ploeg MJ, de Rooij GH, 2013. Satellitebased radar interferometry to estimate large-scale soil water depletion from clay shrinkage: possibilities and limitations. Vadose 
Zone J. doi:10.2136/vzj2012.0098.

Bronswijk JJB, 1991. Relation between vertical soil movements and watercontent changes in cracking clays. Soil Sci. Soc. Am. J. $55: 1220-1226$.

Canny J, 1986. A computational approach to edge detection. IEEE T. Pattern Anal. 8:679-698.

Douglas LH, 2001. A summary of techniques for measuring soil erosion. Environmental performance indicators. Technical Paper No. 69 'Land'. NZ Ministry for the Environment and Regional Councils, Land Monitoring Group.

EC, 2010. Final COMMUNICATION FROM THE COMMISSION EUROPE 2020 A strategy for smart, sustainable and inclusive growth $\operatorname{com}(2010)$.

EC, 2012. Report from the Commission to the European Parliament, the Council, the European Economic and Social Committee and the Committee of the Regions, The implementation of the Soil Thematic Strategy and on going activities (COM(2012) 46 final). Available from: http://ec.europa.eu/environment/soil/three_en.htm

ENRD (European Evaluation Network for Rural development), 2013. Approaches in using common Rural Development indicators in regional RDPs. Good Practice Workshop: Specific challenges in using common RD indicators at regional level. Available from: https://enrd.ec.europa.eu/en/evaluation/evaluation-expert-network

Eltner A, Baumgart P, Maas HG, Faust D, 2014. Multi-temporal UAV data for automatic measurement of rill and interrill erosion on loess soil. Earth Surf. Proc. Land. 40:741-775.

Eurostat, 2013. Agri-environmental indicators - soil erosion. Statistics Explained In Agri-environmental indicators. Available from: h t t p :// e c . e uropa.e u/eurostat/statistics explained/index.php?title=Agri-environmental_indicator__soil_erosion\&printable $=$ yes

Rock G, Ries JB, Udelhoven T, 2011. Sensitivity analysis of UAV-photogrammetry for creating digital elevation models. Available from: http://www.geometh.ethz.ch/uav_g/proceedings/rock

Gross JW, 2015. A comparison of orthomosaic software for use with ultra high resolution imagery of a wetland environment. Center for Geographic Information Science and Geography Department, Central Michigan University, Mt. Pleasant, MI, USA. Available from: http://www.imagin.org/awards/sppc/2015/papers/john_gross_paper. pdf

Grün A, 1985. Adaptive least squares correlation - A powerful image matching technique. S. Afr. J. Photogr. Rem. Sens. Cartogr. 14:175187.

Hammad AA, Lundekvam H, Børresen T, 2004. Adaptation of RUSLE in the eastern part of the Mediterranean Region. Environ. Manage. $34: 829-841$.

Hudson NW, 1993. Field measurement of soil erosion and runoff. FAO
Soils Bulletin, vol. 68. FA0, Rome.

Kimerling AJ, Buckley AR, Muehrcke PC, Muehrcke JO, 2011. Map use: reading, analysis and interpretation, 7th ed. ESRI Press, Redlands, CA, USA.

McCool DK, Foster GR, Mutchler CK, Meyer LD, 1989. Revised slope length factor for the Universal Soil Loss Equation. T. ASAE 32:15711576.

Nearing MA, 1997. A single, continuous function for slope steepness influence on soil loss. Soil Sci. Soc. Am. J. 61:917-919.

Oliveira AH, Aparecida da Silva M, Naves Silva ML, Curi N, Neto GK, Franca de Freitas DA, 2013. Development of topographic factor modeling for application in soil erosion models. In: M.C. Hernandez Soriano (ed.) Soil Processes and current trends in quality assessment. InTech-Open Access.

Rana S, 2006. Use of plan curvature variations for the identification of ridges and channels on DEM. In: A. Riedl, W. Kainz, and G. Elmes (eds.) Progress in spatial data handling. SpringerVerlag, Heidelberg, Germany, pp. 789-804.

Renard KG, Foster GR, Weessies GA, Mccool DK, Yoder DC, 1997. Predicting soil erosion by water: a guide to conservation planning with the Revised Universal Soil Loss Equation (RUSLE). Agriculture Handbook No.703. USDA/Science and Education Administration, US. Govt. Printing Office, Washington, DC, USA.

Soil Survey Staff, 2014. Keys to soil taxonomy, 12th ed. USDA-Natural Resources Conservation Service, Washington, DC, USA

Stroosnijder L, 2005. Measurement of erosion: is it possible? Catena 64:162-173.

USDA, 2015. Soil texture calculator. Natural resources conservation service (soils). Available from: http://www.nrcs.usda.gov/wps/portal/nrcs/detail/soils/survey/?cid=nrcs142p2_054167

Van der Knijff JM, Jones RJA, Montanarella L, 2000. Soil erosion risk: assessment in Europe. European Soil Bureau European Commission Joint Research Centre, Space Applications Institute. Available from: http://www.preventionweb.net/files/1581_ereurnew2.pdf

Wischmeier WH, Smith DD, 1978. Predicting Rainfall erosion losses: a guide to conservation planning. Agriculture Handbook No. 537. USDA/Science and Education Administration, US. Govt. Printing Office, Washington, DC, USA.

Yoder DC, Foster GR, Weesies GA, Renard KG, McCool DK, Lown JB, 2001. Evaluation of the RUSLE soil erosion model. In: J.E. Parsons, D. L. Thomas and R.L. Huffman (eds.), Agricultural non-point source water quality models: their use and application. Available from: http://s1004.okstate.edu/S1004/Regional-Bulletins/ModelingBulletin 